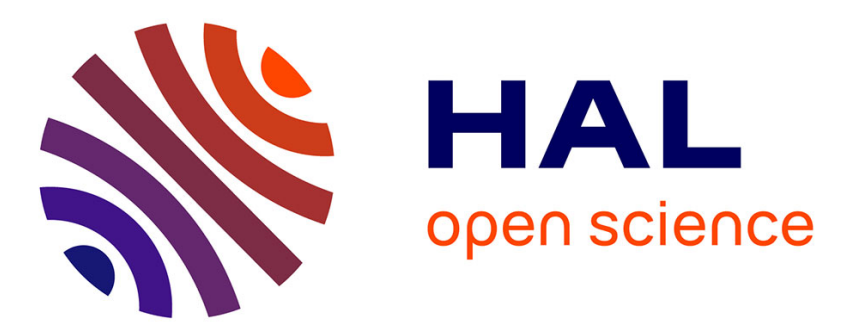

\title{
A review of the current status of siRNA nanomedicines in the treatment of cancer.
}

Pauline Resnier, Tristan Montier, Véronique Mathieu, Jean-Pierre Benoit, Catherine Passirani-Malleret

\section{- To cite this version:}

Pauline Resnier, Tristan Montier, Véronique Mathieu, Jean-Pierre Benoit, Catherine PassiraniMalleret. A review of the current status of siRNA nanomedicines in the treatment of cancer.. Biomaterials, 2013, 34 (27), pp.6429-43. 10.1016/j.biomaterials.2013.04.060 . hal-03178911

\section{HAL Id: hal-03178911 \\ https://univ-angers.hal.science/hal-03178911}

Submitted on 24 Mar 2021

HAL is a multi-disciplinary open access archive for the deposit and dissemination of scientific research documents, whether they are published or not. The documents may come from teaching and research institutions in France or abroad, or from public or private research centers.
L'archive ouverte pluridisciplinaire HAL, est destinée au dépôt et à la diffusion de documents scientifiques de niveau recherche, publiés ou non, émanant des établissements d'enseignement et de recherche français ou étrangers, des laboratoires publics ou privés. 
Review

\title{
A review of the current status of siRNA nanomedicines in the treatment of cancer
}

\author{
Pauline Resnier $^{\mathrm{a}, \mathrm{b}}$, Tristan Montier ${ }^{\mathrm{c}, \mathrm{d}}$, Véronique Mathieu ${ }^{\mathrm{e}}$, Jean-Pierre Benoit ${ }^{\mathrm{a}, \mathrm{b}}$, \\ Catherine Passirani ${ }^{a, b, *}$ \\ ${ }^{a}$ LUNAM Université, F-49933 Angers, France \\ b INSERM U1066, Micro et Nanomédecines Biomimétiques, IBS - CHU, 4 Rue Larrey, F-49933 Angers, France \\ ' INSERM Unité 1078, SFR 148 ScInBioS, Université de Bretagne Occidentale, Université Européenne de Bretagne, 46 Rue Félix Le Dantec, CS51819, \\ 29218 Brest Cedex 02, France \\ d DUMG Université de Bretagne Occidentale, Université Européenne de Bretagne, 22 Avenue Camille Desmoulins, CHRU de Brest, 29200 Brest, France \\ e Laboratory of Toxicology, Faculty of Pharmacy, Université Libre de Bruxelles, Brussels 1050, Belgium
}

\section{A R T I C L E I N F O}

\section{Article history:}

Received 4 April 2013

Accepted 27 April 2013

Available online 30 May 2013

\section{Keywords:}

SiRNA

Delivery system

Cancerology

Systemic injection

Nanomedicine

Pathway targeting

\begin{abstract}
A B S T R A C T
RNA interference currently offers new opportunities for gene therapy by the specific extinction of targeted gene(s) in cancer diseases. However, the main challenge for nucleic acid delivery still remains its efficacy through intravenous administration. Over the last decade, many delivery systems have been developed and optimized to encapsulate siRNA and to specifically promote their delivery into tumor cells and improve their pharmacokinetics for anti-cancer purposes. This review aims to sum up the potential targets in numerous pathways and the properties of recently optimized siRNA synthetic nanomedicines with their preclinical applications and efficacy. Future perspectives in cancer treatment are discussed including promising concomitant treatment with chemotherapies or other siRNA. The outcomes in human clinical trials are also presented.
\end{abstract}

(c) 2013 Elsevier Ltd. All rights reserved.

\section{Introduction}

The RNA interference (RNAi) mechanism was first discovered in plants [1] and demonstrated in the roundworm Caenorhabditis elegans after the microinjection of double-stranded RNA (dsRNA) leading to a transitory high extinction of gene expression [2]. The RNAi concept is based on the interaction of endogen micro-RNA (miRNA) with messenger RNA (mRNA) thanks to the perfect sequence homology observed between the strands [3]. Over the last few years, many kinds of approaches have been created based on the copy or use of this endogenous gene expression regulation system including small hairpin RNA (shRNA; a single strand RNA with a hairpin loop structure), DNA plasmid coding to shRNA, and small-interference RNA (siRNA; a double strand RNA). These structures are all integrated in the miRNA pathway and produce effective gene expression inhibition. This paper will only focus on the RNA form as siRNA (for more information on miRNA, shRNA, see

\footnotetext{
* Corresponding author. INSERM U1066, IBS - CHU, 4 Rue Larrey, 49933 Angers Cedex 9, France. Tel: +33 244688 534; fax: +33 244688546.

E-mail address: catherine.passirani@univ-angers.fr (C. Passirani).
}

review in the bibliography [4]). In the context of gene therapy applied to cancers, siRNA acts as a loss-of-function strategy that can inhibit virtually every single protein of interest expression regardless to its localization within the cells contrary to antibodies or tyrosine kinase inhibitors that respectively react only with surface antigens and tyrosine kinase protein. These small entities aim to modulate the expression of overexpressed or mutated genes identified as a key hurdle. Moreover, thanks to this non-integration in DNA, siRNA does not lead to genome modification, an important parameter for regulatory and safety considerations.

Major hindrance to their clinical development in oncology remains limited pharmacodynamic properties due notably to their physicochemical properties. For these reasons, the association of nucleic acid constructs with a multitude of delivery system [5]. These nanomedicines are necessary in order to protect and help them to cross these natural barriers (see our previous review [6]).

To date, numerous proteins have been targeted by siRNA embedded into non-viral delivery systems in cancer pathologies based on cell cycle, apoptosis, proliferation and angiogenesis pathway studies.

This review i) presents shortly the promising characteristics of nanocarriers to bypass the obstacles of intravenous injection and to 
target specifically cancer cells and ii) sums up the current status of preclinical and clinical studies conducted to date towards various molecular targets in this systemic context. The perspectives and opportunities to use siRNA delivery systems alone or in combination with other therapies are discussed.

\section{SiRNA delivery systems}

SiRNA interacts with cytoplasmic proteins, and in this way need to be taken up by the cell. This mechanism includes the first interaction with cell membrane, the penetration into classic endosomal vesicle or other mechanisms, and finally the escape of this vesicle to be delivered into the cytoplasm. Moreover, siRNA cannot be injected in systemic circulation. In fact, these nucleic acids are rapidly degraded by plasmatic nucleases. In consequence, the encapsulation of siRNA into a delivery system is expected to ameliorate their cell penetration, their delivery into cytoplasm after their protection in blood, their half-life time and finally their specific delivery on tumor site.

\subsection{SiRNA encapsulation}

The encapsulation of hydrophilic drugs such as nucleic acids and proteins has been already developed for numerous formulation processes (Table 1). From the classic liposomes to new triblock micelles, various encapsulation efficiencies have been obtained. High yields (80\%-95\%) have been observed with various types of liposomes based on cationic lipids as 1,2-DiOleoyl-3-TrimethylAmmonium-Propane (DOTAP) [7,8], O,O'-ditetradecanoyl-N- $(\alpha-$ trimethyl ammonio acetyl) diethanolamine chloride (DC-6-14) [9], or cholesterol and their derivates as $3 \beta-\left[\mathrm{N}-\left(\mathrm{N}^{\prime}, \mathrm{N}^{\prime}\right.\right.$-dimethylaminoethane) carbamoyl] cholesterol (DC-cholesterol) [10]. For nanoparticles, lower yield has been evaluated at $40 \%$ with calcium phosphate particle formulation developed by Li et al. [11], however, higher encapsulation efficiency has been observed for calcium phosphate nanoparticle process developed by Pittella and coworkers with $90 \%$ encapsulation yield [12]. For other nanoparticles, yields comprised between $65 \%$ to more than $95 \%$ are described with delivery system using natural lipids as lecithin [13,14], phosphatidylcholine [15], dextran [16], chitosan [17] or modified cholesterol [18] (Table 1). Contrary to liposomes and nanoparticles, complexes and micelles are usually formed with one kind of molecules and the encapsulation efficiency is depending in this case mainly on the lipid/siRNA charge ratio. Complete siRNA interaction was obtained with simple PEI complexes in association with polymer (glycol chitosan) [19] or protein (albumin) [20] and with copolymers as poly(2-(dimethylamino) ethyl methacrylate) (polyDMEAMA) [21], PEG-SS-poly(Pasp-DET) [22] or acetal-poly(ethylene oxide)-block-poly( $\varepsilon$-caprolactone) (acetal-PEO-b-PCL) [23].

However, if yields of encapsulation have been improved for each delivery system, important variations are observed on encapsulated doses of siRNA. While the majority of authors worked with around $200 \mu \mathrm{g}$ by formulation, large scales have been observed from $50 \mu \mathrm{g}[8,11,19]$ up to milligrams [15].

\subsubsection{Cellular uptake}

Nanocarrier proximity with cells can allow their passive penetration into cytoplasm by different mechanisms (Fig. 1). Multitude of

Table 1

Composition and encapsulation efficacy of siRNA delivery systems.

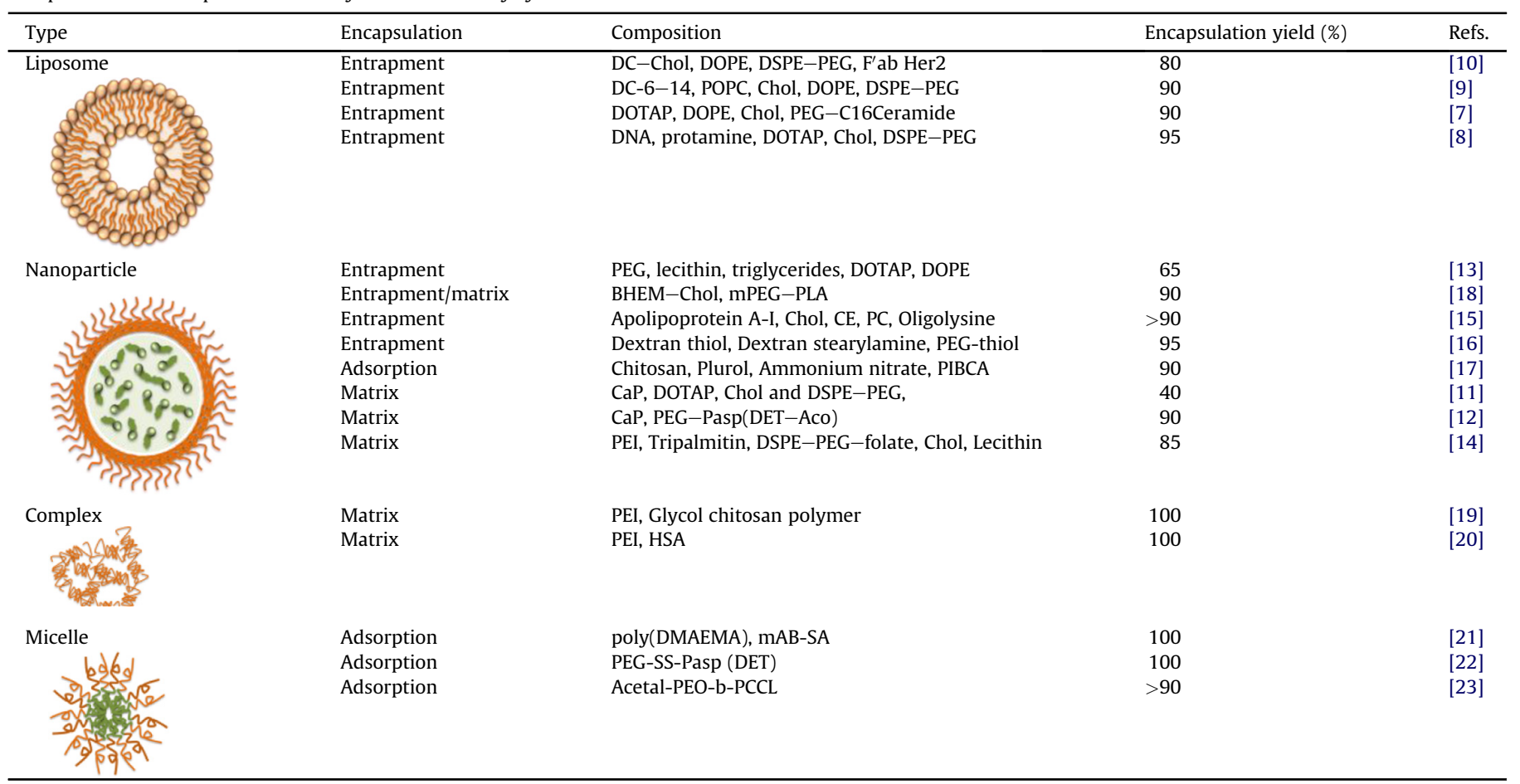

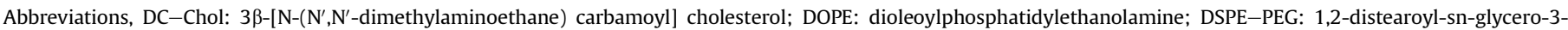

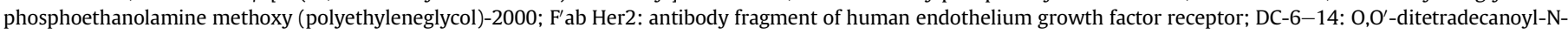

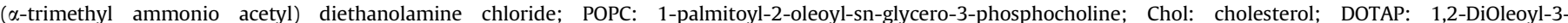

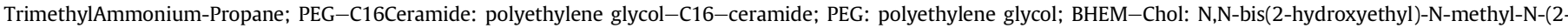

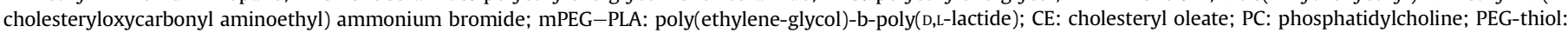

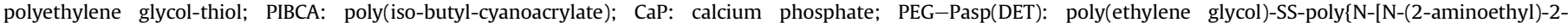

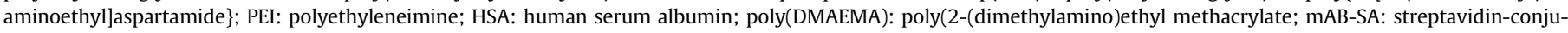
gated monoclonal antibody against CD22; acetal-PEO-b-PCCL: acetal-poly(ethylene oxide)-block-poly( $\varepsilon$-caprolactone). 


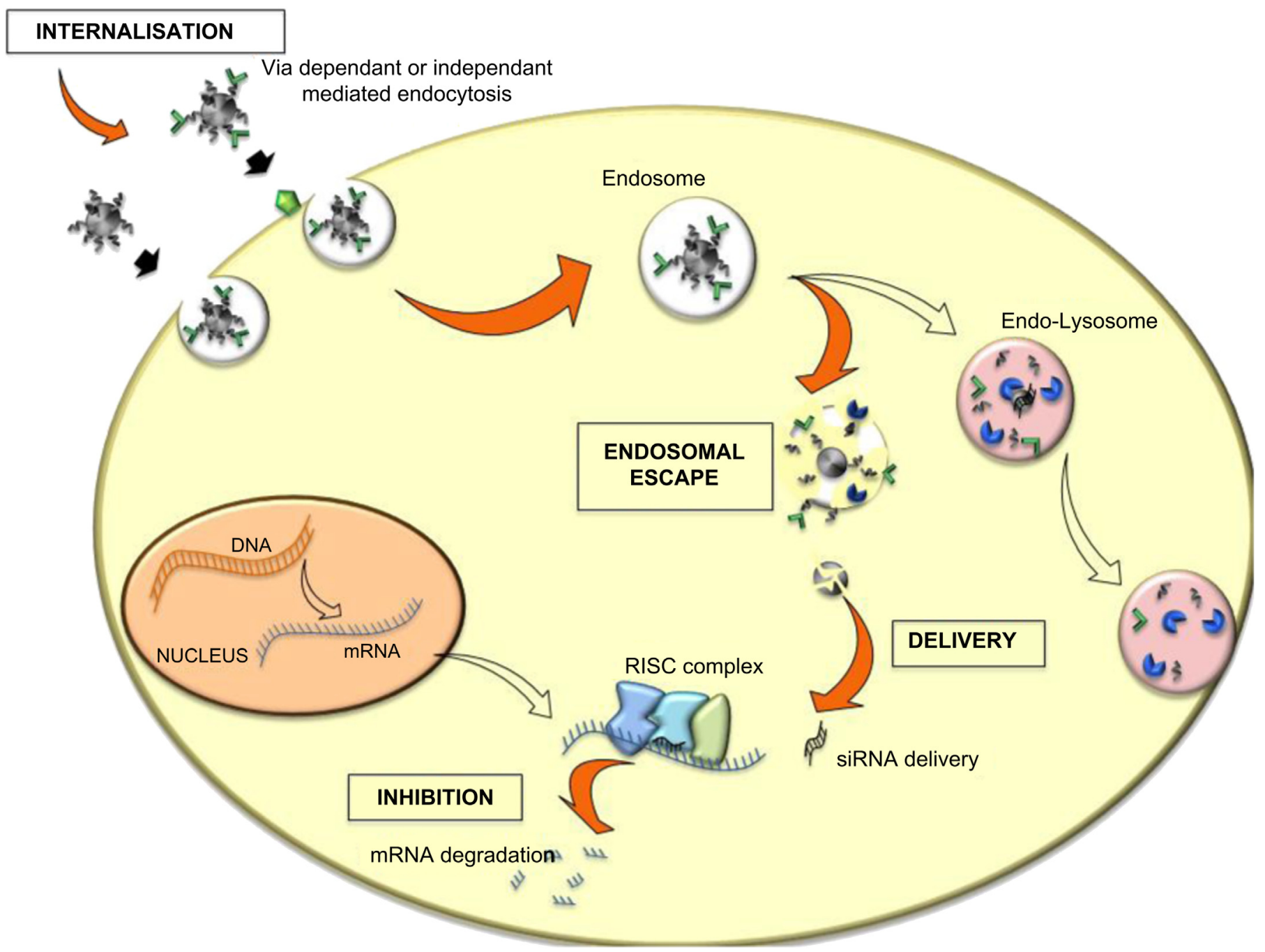

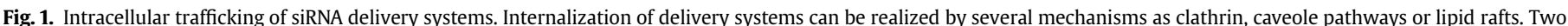

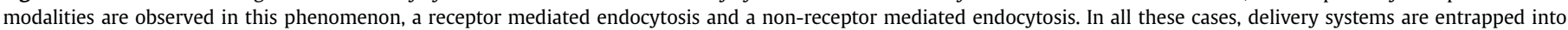

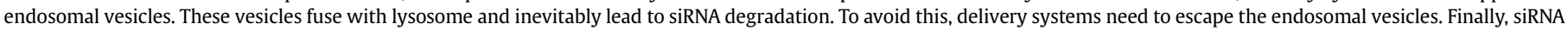
is delivered into the cytoplasm and produces their inhibitor effect.

endocytosis pathways is possible for delivery systems: clathrinmediated endocytosis, lipid raft or caveolae, phagocytosis and macropinocytosis [24]. For example, high-density lipoprotein nanoparticles developed by Shahzad et al., showed efficient cellular uptake with $80 \%$ favored by major lipid compounds [15]. However, the global negative charge created by PEG and required for the stealth properties of delivery systems for passive targeting can prevent cellular uptake by charge repulsion of negative cell membrane. This surface modification can consequently interfere with efficient cellular siRNA delivery. Nonetheless, various pegylated delivery systems have demonstrated their efficiency to entry into cells even with PEG recovery. For example, two kinds of pegylated nanoparticles developed respectively Guo et al. [25] and Yang et al. [18] demonstrated a great cellular uptake with $60 \%$ and up to $95 \%$ of penetrated cells thanks to cholic acid moiety and a cholesterol derivates as N,N-bis(2-hydroxyethyl)-N-methyl-N(2-cholesteryloxycarbonyl aminoethyl) ammonium bromide (BHEM-Chol) contained in shell structure. In addition, cationic lipid (DOTAP and oligolysinoyl lipid) constitution of liposomal forms led to a great cellular uptake with respectively more than $92 \%$ and $100 \%$ of siRNA labeled cells [26,27]. A complete cellular uptake was also obtained by poly(2-aminoethyl ethylene phosphate) (PPEEA) cationic block of micelleplex on breast cancer cells [28]. A high in vitro inhibition was obtained by these micelleplex with $75 \%$ of mRNA and protein extinction $[10,28]$. Then, lipid composition or positive charge is essential point to favor the cellular uptake of delivery system.

The most obvious mechanism for internalization occurs via receptors associated with the ligands used for the active targeting. In this case, receptors mediate endocytosis induced by ligand fixation and this leads to a facilitated internalization of siRNA delivery system in cytoplasmic vesicles through clathrin pathway. For example, in vitro transferrin and integrin targeting on respectively polyplexe and lipoplexe surface resulted in $100 \%$ of cellular uptake on mouse neuroblastoma and human glioblastoma cells $[29,30]$. Two micelle formulations modified with RGD peptide recognizing the $\alpha v \beta 3$ integrins showed a high cellular uptake in breast and ovarian cancer cells, respectively evaluated at $60 \%$ and $70 \%[23,31]$. Finally, endogen molecules as folate can also be used to favor cellular uptake. Indeed, folate receptor expression was correlated with tumor localisation as described recently by Meier et al., in breast cancer [32]. Folate targeted siRNA nanoparticles penetrated at up to $90 \%$ in prostate cancer cells and produced a reduction of $80 \%$ mRNA and protein level in vitro [14]. 


\subsubsection{Endosomal escape}

After internalization, early endosomal vesicles are formed and mature in late endosomes characterized by an acidic $\mathrm{pH}$ and the presence of active enzymes to finally fuse with lysosome vesicles. In these endosomes, the degradation of nanocarriers can be initiated and nucleic acids destroyed by nucleases (Fig. 1). Accordingly, endosomal escape is a critical step for an efficient cytoplasmic siRNA delivery. Two principles have been already advanced to explain the mechanism of endosomal escape by delivery systems [33]. Firstly, proton sponge effect or $\mathrm{pH}$ buffering can be induced by the protonation of entrapped molecules in the acidic $\mathrm{pH}$ medium and produces an important inflow of water and ions as $\mathrm{Cl}^{-}$and $\mathrm{H}^{+}$, resulting in an osmotic swelling allowing the endosomal membrane rupture [34]. As PEG coating at the surface of delivery systems is known to limit the cellular uptake as well as the endosomal escape, new delivery systems have been developed with the view to break down the PEG linker in endosomal vesicle [34]. pH-sensitive linkers have been used in order to loss voluntary PEG chains and highlight the positive charges of polymers or lipids which can promote this proton sponge effect. Effective cytoplasmic localization was demonstrated by Wang et al., with nanoparticles containing $\mathrm{N}$-(1-aminoethyl)iminobis [N-(oleicylcysteinylhistinyl-1-aminoethyl)propionamide] (EHCO) [30]. This polymerizable surfactant EHCO is a $\mathrm{pH}$-sensitive amphiphilic molecule and its use induced a high endosomal membrane disruption [35]. Poly-L-lysine nanocarriers have also been modified to ameliorate their endosomal escape capacity thanks to PEG molecules coupled with cholic acid and a $\mathrm{pH}$ sensitive benzoic imine linker. In acidic conditions, cleavage of this linker was induced. In this way, toxic positive charges of poly-L-lysine became directly in contact with endosomal membrane and conducted to efficient disruption and the release of siRNA into the cytoplasm [25]. PEG-b-poly(propyl methacrylate-co-methacrylic acid) (PEGb-P(PrMA-co-MAA)) polymers associated with PAMAM dendrimer also proved their capacity to avoid the lysosome destruction, $3 \mathrm{~h}$ after incubation [36]. The pH-responsive element was due to protonation of carboxylate groups of MAA and induced the proton sponge effect [37]. This protonation also caused the displacement of PEG-b-P(PrMA-co-MAA) from the dendrimer complex involving a second mechanism of membrane destabilization. Indeed, cationic lipids, polymers or peptides can fuse with endosomal membrane and perturb the bilayer organization thus causing pore and disruption [38]. The use of DOPE, a zwitterionic co-lipid, usually had led to this phenomenon. As an example, DOTAP/ DOPE/cholesterol liposomes induced a cytoplasmic localization of siRNA confirmed by confocal microscopy analysis [39]. Association of DOPE with DC-cholesterol also conduced to an efficient endosomal escape [40]. Intracellular fluorescence was associated to siRNA internalization of DC-cholesterol/DOPE immunoliposomes, $2 \mathrm{~h}$ after incubation on breast cancer cells and resulted in 95\% of mRNA extinction [10]. Otherwise, cholesterol derivate, BHEM-Chol, also induced perturbation into cell/organelle membranes [41] and its use in polymer nanoparticles led to cytoplasmic accumulation and no colocalization with lysosomes evidenced by microscopy analysis [18]. Polymers as PAsp(DET) provided an excellent ability of endosomal destabilization through the conformational change of flanking 1,2-diaminoethane $\mathrm{pH}$ sensitive moiety [42]. Indeed, calcium phosphate nanoparticles surrounded by PAsp(DET) efficiently escaped the endosomal vesicles after $3 \mathrm{~h}$ and showed $80 \%$ of in vitro mRNA extinction [12]. Finally, Varkouhi and coworkers highlighted the potential of peptides in the endosomal escape mechanism. Fusiogenic peptides penetrated into phospholipid bilayers and created a pore provoking swelling choc [33]. Only $2 \mathrm{~h}$ after incubation, sh-GALA peptides combined to liposomes were localized in cytoplasm and confirmed their capacity to fuse with endosomal membrane and disrupt them [26]. In vitro mRNA extinction evaluated at $85 \%$ was induced after $24 \mathrm{~h}$ incubation with this sh-GALA liposomes [26]. Moreover, siRNA-peptide complexes developed by Canine et al., showed a perinuclear localization, demonstrating once again their efficient endosomal escape and in vitro protein extinction evaluated at $95 \%$ [43].

\subsection{SiRNA protection}

\subsubsection{Enzymatic protection}

To deliver intravenously an intact and efficient siRNA to the targeted cells in vivo, the protection of siRNA against plasmatic enzymes as nucleases is the first necessary step to overcome after systemic administration [44]. Naked siRNA is naturally completely degraded in 30 min into the bloodstream after recognition by plasmatic enzymes containing a double-stranded RNA binding domain [45]. To evaluate this degradation in vitro, incubations with serum or RNAse A at physiological temperature have been commonly realized as an indicator of the protection level of siRNA and in vivo evaluation of siRNA protection was realized by half-life study after intravenous injections into rodents (Table 2).

PEI complexes based on PEI alone or on PEI coated with human serum albumin (HSA) or atelocollagen resulted in in vitro and in vivo protection evaluated at less than $1 \mathrm{~h}[20,46-48]$. The commercial form of PEI (JetPEI) provided the best protection with $2 \mathrm{~h}$ of siRNA detection in vitro [49]. In fact, in vitro protein inhibition evaluated at $85 \%$ and $50 \%$ was provided by lipid substituted PEI complexes and PEI-F25 LMW $[28,50]$ and atelocollagen complex with more than $95 \%[14,48]$. However, in vivo analysis highlighted the difficulty of PEI complex to protect and carry siRNA with low transfection efficacy estimated less than $50 \%$ and similar results were found with atelocollagen complex $[14,48]$. An in vitro longer protection, up to $6 \mathrm{~h}$, could be obtained with PEI when it was associated with glycol chitosan and produced $80 \%$ of mRNA extinction [19]. Interestingly,

Table 2

Protection of siRNA by delivery systems.

\begin{tabular}{|c|c|c|c|c|}
\hline Type & Delivery system & $\begin{array}{l}\text { In vitro } \\
\text { protection } \\
\text { (h) }\end{array}$ & $\begin{array}{l}\text { In vivo } \\
\text { protection } \\
\text { (h) }\end{array}$ & Refs. \\
\hline \multirow[t]{6}{*}{ Complexe } & Atelocollagen & 1 & No data & {$[48]$} \\
\hline & PEI & $<1$ & No data & {$[46,47]$} \\
\hline & $\mathrm{PEI} / \mathrm{HSA}$ & $<1$ & No data & {$[20]$} \\
\hline & JetPEI $\left.{ }^{(}\right)$ & 2 & No data & [49] \\
\hline & $\begin{array}{l}\text { Glycol chitosan/PEI } \\
\text { nanoparticle }\end{array}$ & 6 & No data & [19] \\
\hline & $\begin{array}{l}\text { MPG-8 Peptide } \\
\text { based delivery }\end{array}$ & No data & 5 & {$[51]$} \\
\hline \multirow[t]{4}{*}{ Micelle } & $\begin{array}{l}\text { Polyion complex } \\
\text { micelle (PCIM) }\end{array}$ & 4 & No data & {$[36]$} \\
\hline & PLL nanocarrier & 48 & No data & [25] \\
\hline & Micelleplex & No data & 12 & {$[28]$} \\
\hline & $\begin{array}{l}\text { Multifunctional micellar } \\
\text { nanocarriers }\end{array}$ & No data & 24 & {$[23]$} \\
\hline \multirow[t]{6}{*}{ Liposome } & $\begin{array}{l}\text { Her2-PEG- } \\
\text { immunoliposome }\end{array}$ & 9 & No data & {$[10]$} \\
\hline & $\begin{array}{l}\text { Multifunctional } \\
\text { nano-device (MEND) }\end{array}$ & 24 & No data & {$[26]$} \\
\hline & Lipidic particle & No data & $>2$ & {$[7,54]$} \\
\hline & $\begin{array}{l}\text { Pegylated cationic } \\
\text { liposome }\end{array}$ & No data & $>9$ & {$[55]$} \\
\hline & Wrapped liposome & $>3$ & $>6$ & {$[52]$} \\
\hline & Nanoparticle system & 24 & 24 & [53] \\
\hline Nanoparticle & Cyclodextrin nanoparticle & 4 & No data & [56] \\
\hline Dendrimer & PPI dendrimer & 48 & 72 & [58] \\
\hline
\end{tabular}

PEI: polyethyleneimine; HSA: Human serum albumin; PLL: Poly-L-Lysine; PPI: poly(propyleneimine). 
peptide-based delivery with MPG-8 peptide was tested in mice and biofluorescence monitoring (BFI) of siRNA revealed a strong detection until $5 \mathrm{~h}$ after intravenous injection [51].

The micellar organization is in majority composed by hydrophobic block core and hydrophilic block extensions with positive charges siRNA can react with, being absorbed at this interface (Fig. 2). In vitro minimal time of protection induced by micellar systems estimated at $4 \mathrm{~h}$, was obtained by polyion complex micelles (PCIM) and a maximal time, around $48 \mathrm{~h}$, was reported by Guo et al., with PEG-SS-poly-L-lysine-cholic acid (PEG-SS-PLL-CA) nanocarriers $[25,36]$. Furthermore, in vivo validation was realized with two other micellar formulations. Micelleplex and multifunctional micellar nanocarriers demonstrated a long protection time of siRNA, respectively evaluated at $12 \mathrm{~h}$ and $24 \mathrm{~h}[23,28]$. This long protection time allows an effective extinction in vitro and in vivo. In fact, dendrimers developed by Felber et al., inhibited $60 \%$ of the specific mRNA and $50 \%$ of protein in vitro $[36,47]$ and analysis after intravenous injection into mice performed with siRNA poly-Llysine micelles induced $60 \%$ of mRNA inhibition in tumor bearing mice [25].

Liposomes generally entrap siRNA into their aqueous core surrounded by a lipid bilayer shell (Fig. 2). In this case, degradation of siRNA depends on the delivery system stability into the bloodstream. Large variations have been observed between different liposome formulations. In vitro analyses showed a protection of $3 \mathrm{~h}$ and $9 \mathrm{~h}$, respectively for wrapped liposomes [52], and multi-functional nano-devices (MEND) [26], and maximal time of $24 \mathrm{~h}$ have been obtained in some cases [10,53]. Moreover, with immunoliposomes, intravenous injections into mice were performed and blood analyses showed siRNA presence for at least $2 \mathrm{~h}$ and until $24 \mathrm{~h}$. Lipidic particles [7,54], wrapped liposomes [52] and pegylated cationic liposomes [55] allowed an in vivo protection until $2 \mathrm{~h}, 6 \mathrm{~h}$ and $9 \mathrm{~h}$ respectively. Moreover, this protection is illustrated by extinction efficacy obtained with lipidic particle with extinction of mRNA at $70 \%$ in vitro and $60 \%$ in vivo [7]. As for in vitro, nanoparticle systems developed by Yagi et al., provided the longest protection time $(24 \mathrm{~h})$ [53]. Then, the first siRNA delivery system used in clinical test, i.e. cyclodextrin-containing polycations encapsulating siRNA, showed $4 \mathrm{~h}$ of protection after in vitro incubation with RNAse A [56]. Finally, poly(propyleneimine) [57] dendrimers of siRNA were developed by Taratula et al. [58]. This system presented the best protection times in vitro $(48 \mathrm{~h})$ with more than $70 \%$ of mRNA extinction and in vivo $(72 \mathrm{~h})$.

\subsubsection{Protection from immunity and natural clearance}

Innate immune system is naturally developed to detect and degrade extrinsic unknown objects as foreign delivery systems. Specific organs as liver, spleen and kidneys play a crucial role in

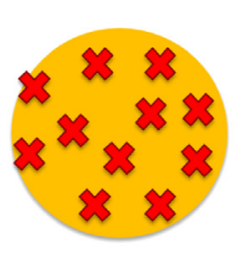

MATRIX
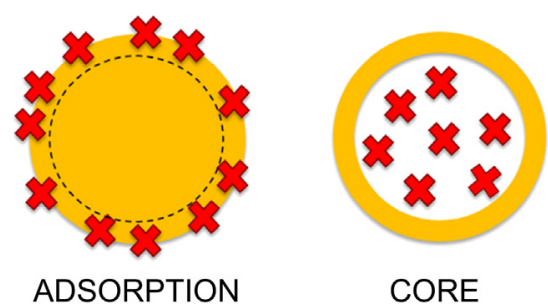

CORE
Fig. 2. Methods of siRNA complexation with delivery systems. The siRNA localization into nanocarriers differs according to structure and organization of the delivery system. SiRNA can be incorporated into matrix structure and allows a global repartition in all volume of sphere (left). Second strategy consists to adsorb siRNA on surface of delivery systems in low depth (middle scheme). Last organization concerns shell/core structure observed for liposomes and some nanoparticles. In this case (right), siRNA is restrained in the core compartment of the delivery system. their pharmacokinetic behavior as part of the reticulo-endothelial system (Fig. 3). In fact, the mononuclear phagocyte system (MPS) mainly situated in liver, represents a monocyte/macrophage rich zone that promotes filtration, capture and destruction of blood components as cellular fragments, bacteria, aggregates and also nano-objects [59]. Moreover, kidney by renal clearance mechanism controls the elimination of these delivery systems [59]. Important clearance appears when system diameter is less than $25 \mathrm{~nm}$ [60] (Fig. 3). Delivery systems whom size is comprised between 50 and $250 \mathrm{~nm}$, can largely limit their degradation or elimination by these different mechanisms and increase their half-life in bloodstream. To illustrate this, a large majority of nanocarriers already developed for in vivo applications have their size comprised in this interval (Table 3).

The surface charge of the delivery systems is also a critical parameter to consider in order to obtain a suitable pharmacokinetic profile. Indeed, plasmatic proteins are negatively charged and can consequently form some aggregates with positive charges. These large complexes can be recognized by innate immune system (complement proteins or macrophages). The bricks of the complement are able to interact with plane surface and favor macrophage recruitment $[60,61]$. The endocytosis by macrophages can lead to the destruction of the delivery systems and thus siRNA. By presenting neutral or slightly negative charge at the surface, complement fixation and recognition by MPS can be avoided or largely limited (Fig. 3). To illustrate this, nanoparticles can present neutral or negative global charge, as mesoporous nanoparticles developed by Tanaka et al., or lipoprotein nanoparticles of Shahzad et al., (both with $-3 \mathrm{mV}$ ) and LNCs with $+7 \mathrm{mV}$ of surface charge $[13,15,57]$. For other nanoparticles cited in Table 3, PEG has been added at the surface to create artificially a negative hydrophilic and flexible ring which can hide and limit the effect of positive charges of cationic lipids and/or polymers used for the complexation of siRNA. Indeed, PEG is able to modify zeta potential of nanoparticles thanks to dipole interactions with water [62]. In fact nanoparticles developed respectively by Yang et al., and Susa et al., exhibited negative or neutral global charge thanks to this PEG recovery [16,18]. PEI polymer provided the similar effect and led, for example, to a negative charge of $-21 \mathrm{mV}$ for solid hybrid PEI nanoparticles [14].

For micelles, copolymers like poly(DMAEMA) and PEO-b-PCL induce generally a neutral profile $[21,23]$. Furthermore, micelles can resort to pegylation in order to neutralize positive charge of block copolymers. For example, PCIM with PEG ring, were characterized by neutral zeta potential evaluated at $+5 \mathrm{mV}$ [36], and micelleplex developed by Mao et al., had largely negative global charge with a zeta potential of $-21 \mathrm{mV}$ [63].

Concerning peptide complexes, they present generally a slight positive charge as observed for peptide-based nanoparticles, and FDT nanocarriers with respectively +16 and $+10 \mathrm{mV}$ [43,51]. Same results were obtained with glycol chitosan/PEI complexes $(+10 \mathrm{mV})$ [19] and other polymer complexes based on oligoethyleneimine derivates (OEI-HD) $(-6 \mathrm{mV})$ [29].

In the case of liposomes, pegylation is a necessary step to hide the high level of positive charges due to cationic headgroups. Even with PEG recovery, zeta potentials can stay highly positive as it is the case for liposomes of polycation hyaluronic acid (LPH) [64], liposomes polycation DNA (LPD) [8,65], lipidic particles [7] and pegylated cationic liposomes [55] characterized by a zeta potential comprised between +11 and $+48 \mathrm{mV}$ (Table 3 ). Despite these positive charges, lipidic particles and pegylated cationic liposomes developed respectively by $\mathrm{Wu}$ et al., and Sonoke et al., allowed an in vivo long time circulation and protection of siRNA explained by an efficient steric repulsion due to the high flexibility and hydrophilicity of PEG [62]. 


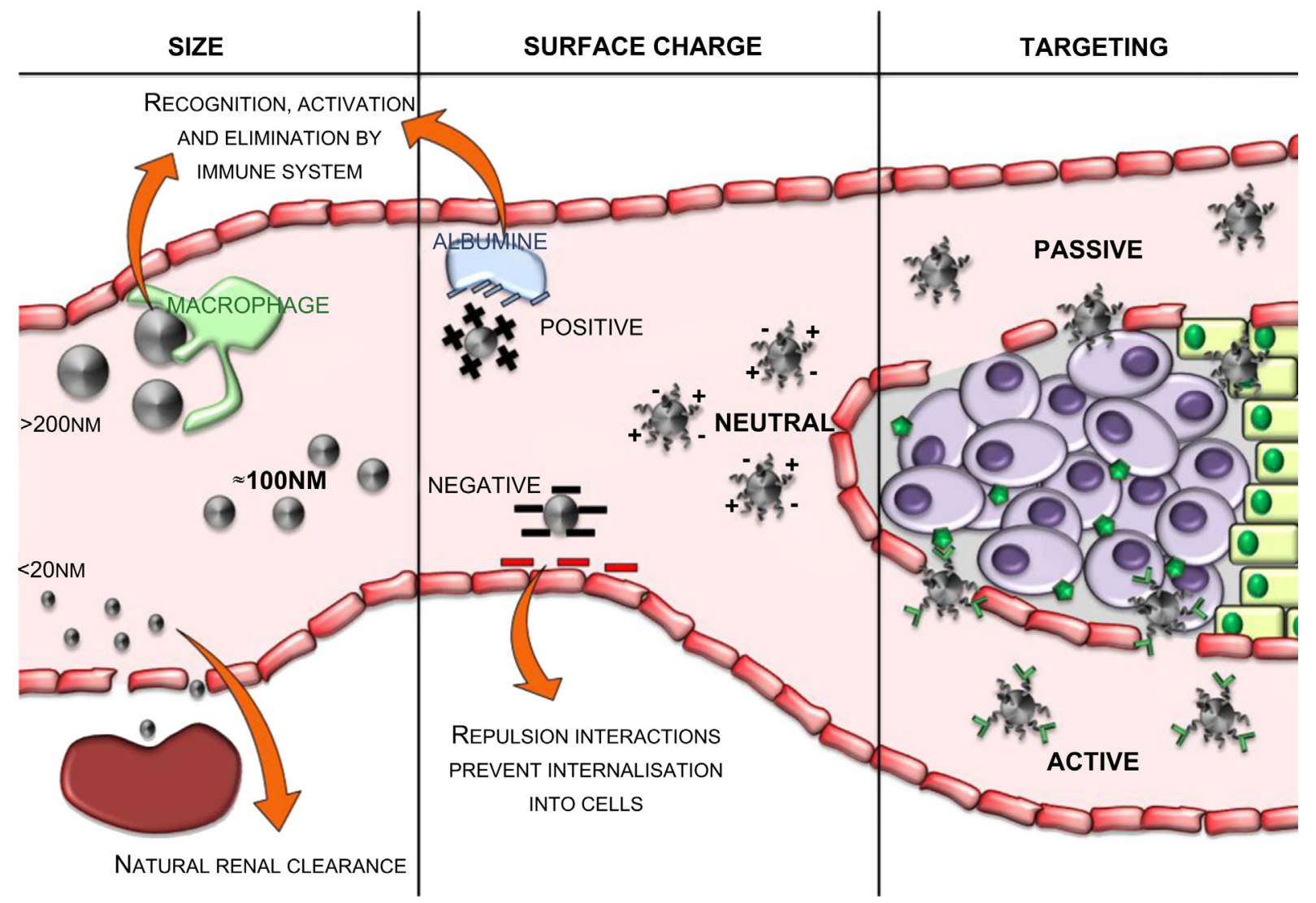

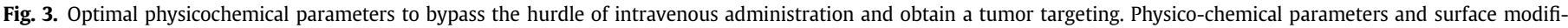

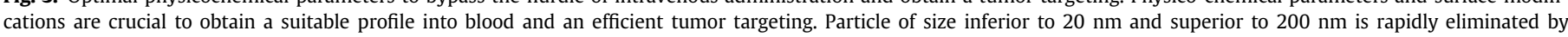

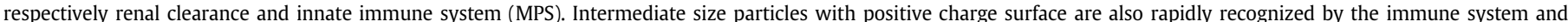

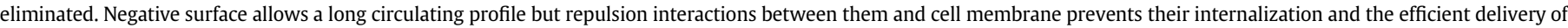

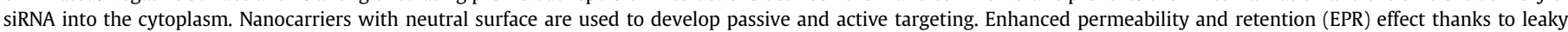
vasculature allows a passive targeting of tumor site. Finally, active strategy with specific ligand induces the internalization of delivery systems into cancer cells.

\subsection{Tumor targeting}

\subsubsection{Passive targeting}

The advantage of delivery systems is to favor cellular uptake and target only tumor site and tumoral cells, in order to limit side effects and improve the therapeutic efficacy. Large fenestrations have been described on vessels situated around the tumor and they are associated with poor lymphatic drainage favoring the retention [66]. All of this provokes the Enhanced Permeability and Retention (EPR) effect demonstrated by Maeda et al., and leads to the development of passive targeting strategy consisting in natural accumulation in tumor site by long circulating or stealth delivery systems [66] (Fig. 3).

Numerous siRNA liposomes recently demonstrated this tumoral targeting. Neutral non-pegylated mesoporous silicon nanoparticles developed by Tanaka et al., and liposomes developed by Halder et al., have obtained a high tumor protein extinction superior at $80 \%$ after systemic injection into mice and consequently proved the accumulation of delivery system into tumor cells [57,67]. Passive accumulation was also achieved after single intravenous injection of fluorescent siRNA into pegylated LPD nanoparticles [68]. Cervical mouse cancer was successfully passively targeted by pegylated siRNA loaded lipid particles [7] and in vivo analysis highlighted an effective extinction estimated at more than 95\% [65,69] Recently, novel pegylated cationic liposomes proved their efficacy to target pulmonary metastatic melanoma [9]. Moreover, synthetic polymers as PEI complex used by Grzelinski et al., allowed an efficient passive targeting of glioblastoma xenograft [46]. Then, new polymer, EHCO complexed with siRNA, was injected intravenously and demonstrated tumor site accumulation with 65\% of protein extinction [29,30]. Micelleplex formed with triblock copolymer promoted breast cancer accumulation $4 \mathrm{~h}$ after intravenous injection [28]. Finally, Alexa555 siRNA lipoprotein nanoparticles were localized in ovarian tumor $48 \mathrm{~h}$ after a single intravenous administration 15].

Nonetheless, this strategy presents some limitations. EPR effect allows extravasation through inflammatory endothelium that possesses large fenestrations but does not lead to an exclusive cancerous cell targeting. Moreover, differential degree of vasculature, angiogenesis as well as tumor type, maturity and host environment, can play an important role in this EPR effect. Consequently, active targeting could be a way to enhance delivery system accumulation in desired tumor site and to help internalization into tumor cells.

\subsubsection{Active targeting}

In parallel to a passive clustering, an active targeting is more and more envisaged to enhance the preferential tumor accumulation and avoid side toxic effect. This can be obtained by grafting at the surface of the delivery system markers or ligands only expressed or at least overexpressed in tumors (tumoral environment or tumoral cells) (Fig. 3). For this purpose, chemical modifications on polymers have allowed the fixation of many families of molecules as peptides, antibodies and/or glucides (see Ref. [6]). 
Table 3

Physico-chemical characteristics of siRNA delivery systems.

\begin{tabular}{|c|c|c|c|c|}
\hline Type & Delivery system & $\begin{array}{l}\text { Diameter } \\
{[117]}\end{array}$ & $\begin{array}{l}\text { Zeta potential } \\
(\mathrm{mV})\end{array}$ & Refs \\
\hline \multirow[t]{6}{*}{ Nanoparticle } & Mesoporous silicon particle & 26 & -3 & [57] \\
\hline & Lipoprotein nanoparticle & 10 & -3 & [15] \\
\hline & Lipid nanocapsule (LNC) & 60 & -7 & [13] \\
\hline & Dextran nanoparticle & 105 & -0.2 & [16] \\
\hline & PEG-PLA nanoparticle & 196 & -17 & [18] \\
\hline & $\begin{array}{l}\text { Lipid - PEI hybrid } \\
\text { nanocarrier (LPN) }\end{array}$ & 210 & -21 & [14] \\
\hline \multirow[t]{4}{*}{ Micelle } & pH-responsive micelle & 35 & 1 & [21] \\
\hline & $\begin{array}{l}\text { Multifunctional } \\
\text { micellar nanocarrier }\end{array}$ & 103.4 & 4 & [23] \\
\hline & $\begin{array}{l}\text { Polyion complex } \\
\text { micelle (PCIM) }\end{array}$ & $50-100$ & 5 & [36] \\
\hline & Micelleplex & 47.7 & -21 & [63] \\
\hline \multirow[t]{4}{*}{ Complexe } & Peptide based nanoparticle & $100-150$ & 16 & [51] \\
\hline & FDT & 78 & 10 & [43] \\
\hline & $\begin{array}{l}\text { Glycol chitosan/PEI } \\
\text { nanoparticle }\end{array}$ & 350 & 10 & [19] \\
\hline & Polyplexes & $155 \pm 3$ & -6 & [29] \\
\hline Dendrimer & PPI dendrimer & $101 \pm 43$ & No data & [58] \\
\hline \multirow[t]{5}{*}{ Liposome } & $\begin{array}{l}\text { Liposome polycation } \\
\text { hyaluronic acid (LPH) }\end{array}$ & 170 & 11 & [64] \\
\hline & $\begin{array}{l}\text { Liposome polycation } \\
\text { DNA (LPD) }\end{array}$ & 114 & 25 & [8] \\
\hline & $\begin{array}{l}\text { Liposome polycation } \\
\text { DNA (LPD) + NGR }\end{array}$ & 197 & 31 & [65] \\
\hline & Lipidic particle & 179 & 41 & [7] \\
\hline & Pegylated cationic liposome & 100 & 48 & [55] \\
\hline
\end{tabular}

PEG-PLA: poly(ethylene-glycol)-b-poly(D,L-lactide); PEI: polyethyleneimine; FDT: fusiogenic peptide - DNA condensing and endosomolytic motif - targeting motif; PPI: poly(propyleneimine).

Transferrin delivery system has demonstrated their efficacy to target tumor cell as transferring conjugated OEI-HD polyplexes with $85 \%$ of protein extinction in tumor cell after intravenous injection $[29,30]$ and transferrin cyclodextrin-based nanoparticles with in vivo protein inhibition on murine model with a decrease estimated at $55 \%$ [70].

Tumor homing peptides are able to react with different receptors as, for example, integrin receptors with RGD peptide. In fact, Arg-Gly-Asp (RGD) motif is implicated in the fixation of alpha $\mathrm{V}$ integrin proteins on their receptor overexpressed on tumoral vessels [71]. Recently, two micelle formulations modified with RGD showed an efficient in vivo tumoral targeting in breast and ovarian cancer cells [23,31]. In fact, RDG chitosan nanoparticles showed in vivo mRNA and protein extinction respectively at $80 \%$ and $51 \%$ [31]. Moreover, in vivo experiments were also performed with RGD liposome delivery systems and conduced to a half-inhibition of protein expression in breast cancer cell bearing mice [39]. Another example has been prepared with the Asn-GlyArg (NGR) motif, discovered by phage display technology, that is able to interact with aminopeptidase $\mathrm{N}$ receptor (or CD13) [72]. The expression of this receptor was correlated with cancerous angiogenic property and cell mobility [73]. NGR liposomes were used by Chen et al., to target actively tumor vessels in sarcoma model and resulted in an efficient tumoral accumulation [65]. AlaPro-Arg-Pro-Gly (APRPG) peptide targets angiogenesis vessels as RGD and NGR $[74,75]$ and was efficient on the surface of liposome formulation to induce an active in vivo tumor accumulation in colon tumor bearing mice [76]. Otherwise, peptide sequence isolated from releasing protein as hormone can be used to target specific cells or organs. For example, luteinizing hormonoreleasing hormone (LHRH) plays an important role in multiple malignancies as cancer [77]. LHRH receptor has been described as a potential target for various cancers as hormone-dependent one [78]. A synthetic analog peptide was conjugated to siRNA dendrimers and provided an efficient and selective tumoral accumulation in ovarian cancer model [58].

In parallel, other molecules including for example polyunsaturated fatty acids, folic or, hyaluronic acids, can be used for active targeting [79]. Hyaluronic acid participates in cell growth, differentiation and migration [80] and is overexpressed in various cancers $[81,82]$. Chen et al., used a strategy based on hyaluronic acid grafted on pegylated liposomes and showed a preferential tumor localisation in melanoma bearing mice [64].

Antibodies have also been used to target specific cell receptors. Transferrin plays a major role in cell growth and its expression has been correlated with cancer progression. Antibodies of transferrin receptors have been largely used to target actively cancer cells $[83,84]$. For example, Pirollo et al., grafted an anti-transferrin antibody fragment on liposome to induce an active targeting of prostate and/or pancreatic model, observed as soon as $20 \mathrm{~min}$ after intravenous injection [85].

\section{Current targets of siRNA in cancer therapy development}

Good candidates for gene silencing in cancer therapy are legion when considering in vitro demonstration and/or use that are associated with anti-cancer effects. Few of them are nevertheless in the pipelines of pharmaceutical companies. General concerns about the targets to be considered for further drug development could be 1) differential expression level between cancer $v s$ non-cancerous cells (generally overexpression in cancer cells; cancer type specificity should thus be considered as well as personalized medicine), 2) genetic concerns, e.g. highlighting the target to be associated with spontaneous cancer development in animal models and viability of the knock out models to decrease risk of toxicity (targeted delivery systems can be used to overcome, at least partly this problem), 3) characterized and crucial roles in cancer development, progression, resistance..., 4) multiple functionalities and/ or localizations (in particular intracellular proteins) that cannot be inhibited by chemicals or reached by other therapeutic tools such as antibodies, 5) cellular half-life: protein with very rapid turn-over will increase the difficulty to develop a vector that can be administered in a practical point of view to obtain appropriate knock down timelines.

In this section we considered the different targets/pathways for which in vivo animal studies have been conducted successfully (Fig. 4). Table 4 summarizes these studies with detailed formulation, protocol and results.

\subsection{Cell cycle}

Cell cycle progression is strictly controlled as demonstrated in 1989 by Hartwell and Weinert by numerous effectors and checkpoints [86]. Main effectors of cell cycle progression are cyclins and cyclin-dependant kinases (cdk) such as cyclin B1-cdk1 complex which is the main effector implicated in G2/M transition [87]. Numerous studies have proven the overexpression of cyclin B1 in various cancers as oesophageal squamous cancer [88], non-small lung cancer [89], renal cancer [90] and prostate adenocarcinoma and was recently associated with a poor survival prognosis in breast cancer [91]. Cyclin B1 siRNA inhibition strategy was employed in prostate and lung cancer in vivo [51]. Eight intravenous injections of $10 \mu \mathrm{g}$ siRNA complexed with peptide-based delivery systems to mice produced a reduction of about $92 \%$ of the prostate tumoral volume (Table 4). In a sub-cutaneous lung cancer model, tumor reduction reached $70 \%$ and half of the animals treated presented longer survival periods [51].

Polo-like-kinase 1 (Plk1) plays key roles during mitosis notably in the activation of cyclin B1-cdk1 complex and anaphase- 


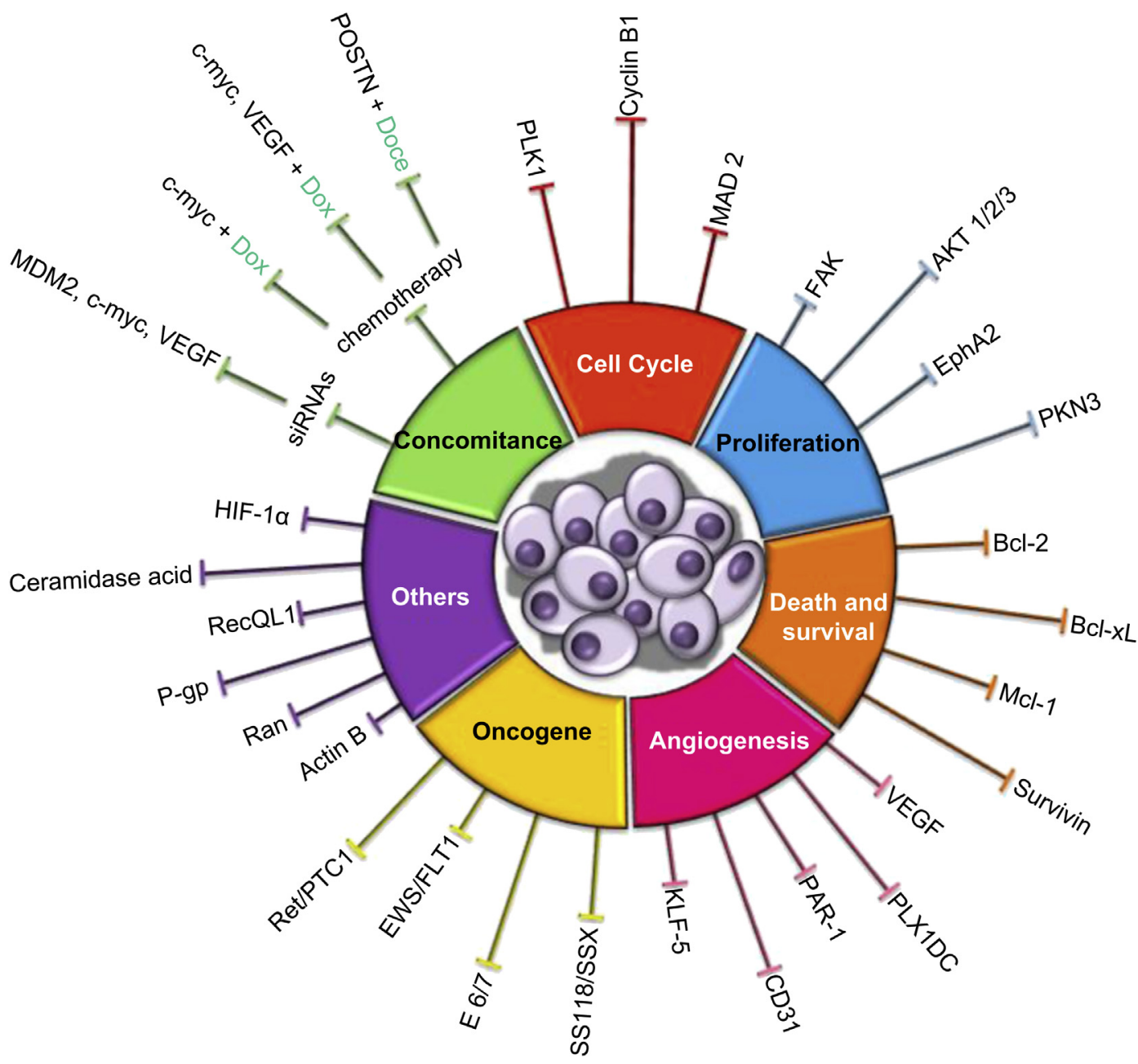

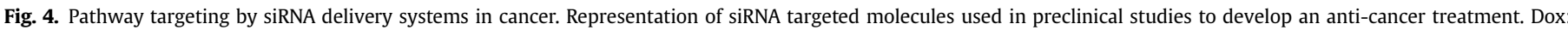

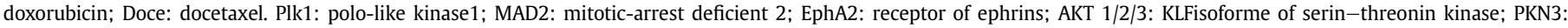

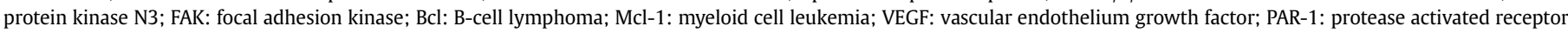

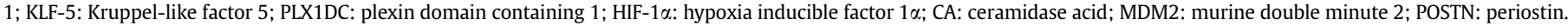

promoting complex/cyclosome (APC/C) for G2/M transition and spindle assembly checkpoint respectively [92]. Plk1 is overexpressed in multiple cancer types, including melanoma [93], nonsmall cell lung cancer [94], colorectal cancer [95], and breast cancer [96], with for some of them bad prognosis values. Inhibitions by siRNA or chemical agents validated Plk1 as an interesting target to combat cancer [97,98]. Two recent studies described Plk1 siRNA delivery systems. Sun et al., developed a micelleplex that was injected daily intravenously in sub-cutaneous breast tumor bearing mice from twelve days after tumor implantation to the end of the protocol at a siRNA concentration of $220 \mu \mathrm{g} / \mathrm{kg}$. This treatment led to $70 \%$ of tumoral volume reduction compared to control group [28]. This protocol also demonstrated the recovery of effective apoptotic pathways with activation of caspase 3 . A second study was realized on a breast organotypic tumor model. Treatment with Plk1 siRNA in PEG-PLA nanoparticles led to a 75\% tumor growth inhibition after seven intravenous injections of $20 \mu \mathrm{g}$ siRNA each [18].

Other checkpoint effectors' knock down could be useful to combat cancer, e.g. mitotic-arrest deficient 2 protein (MAD2) which is involved in the regulation of SAC [99]. MAD2, through sequestration of $\mathrm{CDC} 20$ into a complex, inhibits $\mathrm{APC} / \mathrm{C}$, maintains thereby the sisters' chromatids together till all chromosomes are bi-oriented to each spindle pole on metaphase plate, in order to prevent mis-segragation [100]. Liver cancer [101], lymphoma [102], lung [103], colon carcinoma [104], express high levels of MAD2. This upregulation of this SAC regulator is associated with mitotic delay and chromosome instability that finally contributes to hallmarks of cancer as aneuploidy and genetic instability [10]. Knock down of MAD2 led to pro-apoptotic effects in osteasarcoma [105]. Kaestner et al., administered PEI/anti MAD2 siRNA complex intravenously MAD2 siRNA to sub-cutaneous colon carcinoma bearing mice. Injections of $10 \mu \mathrm{g}$ of siRNA every two days during 14 days inhibited tumor growth of $35 \%$ [69].

\subsection{Proliferation pathways}

Cancer cells are characterized by sustained proliferation resulting from increased proliferative signals, decrease of negative feed-back signals and replicative immortality acquisition [10]. Cancer cells produce or force their environment to produce excessive growth factors as for example insulin growth factor (IGF), or epidermal growth factor (EGF) [106] but can become independent of these signals with mutations. Such external stimuli activate intracellular cascades like the MAPK pathways or the phosphoinositide-3-kinase (PI3K)/serin-threonin kinase AKT one, that promotes proliferation, division and survival and were clearly described in cancerogenesis mechanism [107]. EphA2 is a specific 
Table 4

Protocol based on siRNA delivery in cancer therapy.

\begin{tabular}{|c|c|c|c|c|c|c|c|c|c|c|}
\hline \multicolumn{2}{|l|}{ Pathway } & SiRNA target & Cancer model & $\begin{array}{l}\text { Tumoral } \\
\text { cell injection }\end{array}$ & $\begin{array}{l}\text { Total } \\
\text { dose }(\mu \mathrm{g})\end{array}$ & $\begin{array}{l}\text { Number of } \\
\text { injections }\end{array}$ & $\begin{array}{l}\text { Day of } \\
\text { injection }\end{array}$ & $\begin{array}{l}\text { Inhibition } \\
\text { of tumor } \\
\text { volume }\end{array}$ & Other effects & Refs. \\
\hline \multirow{4}{*}{\multicolumn{2}{|c|}{ Cell cycle }} & Cyclin B & Prostate & s.c & 80 & 8 & D0-21 & $70 \%-92 \%$ & $50 \%$ long survival & [51] \\
\hline & & Plk1 & Breast & S.c & 141 & 32 & D12-44 & $70 \%$ & Caspase 3 activation & [28] \\
\hline & & & & Orthotopic & 140 & 7 & D14-21 & $75 \%$ & 1 & [18] \\
\hline & & MAD2 & Colon & S.c & 70 & 7 & D0-14 & $35 \%$ & Increased apoptosis & [69] \\
\hline \multirow{6}{*}{\multicolumn{2}{|c|}{ Proliferation }} & EphA2 & Ovarian & i.p & 5 & 1 & D15 & $55 \%$ & 1 & [57] \\
\hline & & AKT1 & Prostate & s.c & 600 & 6 & D0-15 & $66 \%$ & i & [114] \\
\hline & & AKT2 & Prostate & s.c & 600 & 7 & D0-16 & $89 \%$ & i & [114] \\
\hline & & АКТ3 & Prostate & s.c & 600 & 8 & D0-17 & $57 \%$ & i & [114] \\
\hline & & PKN3 & Prostate & Orthotopic & 224 & 4 & D1-4 & $60 \%$ & $75 \%$ for metastasis & [117] \\
\hline & & FAK & Ovarian & i.p & $24-30$ & $8-10$ & D7-31 or 38 & $60 \%$ & l & [31] \\
\hline \multirow{4}{*}{\multicolumn{2}{|c|}{$\begin{array}{l}\text { Cell death and } \\
\text { Survival }\end{array}$}} & Bcl-2 & Prostate & s.c & 2000 & 10 & D10-21 & $65 \%$ & l & [55] \\
\hline & & Bcl-xL & Prostate & s.c & 1200 & 12 & D1-24 & $40 \%$ & No inflammatory response & [48] \\
\hline & & Mcl-1 & Breast & s.c & 140 & 7 & D9-19 & $75 \%$ & $\begin{array}{l}\text { Maximal dose tested } \\
53 \mathrm{mg} / \mathrm{kg}=\text { no toxicity }\end{array}$ & [27] \\
\hline & & Survivin & Prostate & S.c & 14 & 2 & D2 and D7 & $30 \%$ & I & [14] \\
\hline \multirow{8}{*}{\multicolumn{2}{|c|}{ Angiogenesis }} & VEGF & Prostate $^{a}$ & S.c & 7000 & 7 & $50 \mathrm{~mm}-\mathrm{D} 0-18$ & $53 \%$ & No inflammatory response & [25] \\
\hline & & & Prostate & s.c & 560 & 5 & D0-28 & $87 \%$ & No inflammatory response & [144] \\
\hline & & PAR-1 & Melanoma & s.c & 80 & 8 & $\begin{array}{l}3-5 \mathrm{~mm}- \\
\mathrm{D} 0-\mathrm{D} 28\end{array}$ & $77 \%$ & I & [168] \\
\hline & & & Melanoma meta & i.v & 100 & 10 & D0-35 & 1 & $\begin{array}{l}\text { Decreased metastase } \\
\text { number }(81 \%)\end{array}$ & [168] \\
\hline & & CD31 & Prostate & Orthotopic & 350 & 8 & D35-49 & $65 \%$ & I & [117] \\
\hline & & KLF-5 & Lung carcinoma ${ }^{a}$ & S.C & 350 & 7 & $\mathrm{D} 2-8$ & $60 \%$ & i & [53] \\
\hline & & & Prostate & S.c & 1500 & 10 & D7-16 & $48 \%$ & Prolonged survival median & [53] \\
\hline & & PLX1DC & Ovarian & i.p & $24-30$ & $8-10$ & D7-31 or 38 & $87 \%$ & Increased apoptose (35\%), & [31] \\
\hline \multirow{5}{*}{\multicolumn{2}{|c|}{ Oncogene protein }} & $\mathrm{E} 6 / 7$ & Renal $^{\mathrm{a}}$ & s.c & 120 & 3 & D3-10 & $55 \%$ & $\begin{array}{l}\text { No synergic effect with } \\
\text { cisplatin }\end{array}$ & [7] \\
\hline & & & Renal $^{\mathrm{a}}$ & i.v & 320 & 4 & D1-11 & 1 & $\begin{array}{l}\text { Prolonged median survival } \\
\text { 31D vs 21D }\end{array}$ & [7] \\
\hline & & ret/PTC1 & Fibroblast & s.c & 100 & 5 & D0-9 & $90 \%$ & 1 & [17] \\
\hline & & EWS-FLI1 & Ewing sarcoma & i.v & 400 & 8 & D1-24 & $80 \%$ & No inflammatory response & [70] \\
\hline & & SS18-SSX & Synovial sarcoma & S.c & 1000 & 10 & D3-28 & $83 \%$ & l & [52] \\
\hline \multirow[t]{8}{*}{ Other pathways } & Hypoxy & HIF-1a & Glioblastoma & s.c & 300 & 6 & D21-36 & $50 \%$ & l & [30] \\
\hline & Metabolism & CA & BT474 & S.c & 240 & 12 & D10-22 & $75 \%$ & $\begin{array}{l}\text { Increased apoptosis, } \\
\text { non-immunogenic }\end{array}$ & [63] \\
\hline & DNA repair & RecQL1 & Colorectal meta & Spleen & 500 & 10 & D4-25 & $43 \%$ & I & [154] \\
\hline & & & Pancreatic meta & Spleen & 250 & 10 & D4-15 & $31 \%$ & i & [154] \\
\hline & & & Lung & s.c & 400 & 8 & D8-32 & $46 \%$ & i & [154] \\
\hline & $\begin{array}{l}\text { Nuclear } \\
\text { transport }\end{array}$ & Ran & Neuroblastoma $^{a}$ & s.c & 150 & 3 & D7-13 & $49 \%$ & $\begin{array}{l}\text { Increased apoptotic } \\
\text { cell }(12 \%), \text { no hepatic } \\
\text { toxicity }\end{array}$ & [29] \\
\hline & Resistance & P-gp & Breast $^{\mathrm{a}}$ & S.c & 160 & 4 & D11-17 & $60 \%$ & l & [39] \\
\hline & Migration & Actine B & HT-1080 & S.C & 320 & 4 & D11-D14 & $65 \%$ & No inflammatory response & [26] \\
\hline \multirow{2}{*}{\multicolumn{2}{|c|}{ SiRNA concomitance }} & $\begin{array}{l}\text { MDM2, } \\
\text { c-myc, VEGF }\end{array}$ & Melanoma $^{a}$ & i.v & 18 & 2 & D8 and 9 & $30 \%$ & No inflammatory response & [64] \\
\hline & & $\begin{array}{l}\text { MDM2, } \\
\text { c-myc, VEGF }\end{array}$ & Melanoma ${ }^{\mathrm{a}}$ & i.v & 36 & 4 & D10-18 & 1 & $\begin{array}{l}\text { Increased survival } \\
\text { median }+6 D \text {, no } \\
\text { inflammatory response }\end{array}$ & {$[8]$} \\
\hline \multirow{3}{*}{$\begin{array}{l}\text { Chemotherapy } \\
\text { Concomitance }\end{array}$} & Doxorubicin & c-myc & Colon & S.c & 72 & 3 & D1-3 & $60 \%$ & Increased apoptosis & [65] \\
\hline & Doxorubicin & c-myc, VEGF & Ovarian & S.c & 72 & 3 & D1-3 & $57-60 \%$ & $\begin{array}{l}\text { Increased apoptosis, } \\
\text { no inflammatory response }\end{array}$ & [68] \\
\hline & Docetaxel & POSTN & Ovarian & i.p & $24-30$ & $8-10$ & D7-31 or 38 & $90 \%$ & $\begin{array}{l}\text { Increased apoptose ( } 45 \%) \text {, } \\
\text { decreased proliferation } \\
(60 \%)\end{array}$ & [31] \\
\hline
\end{tabular}

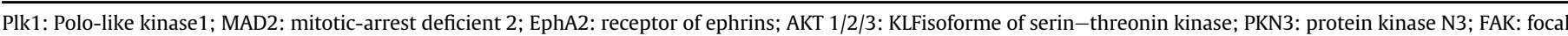

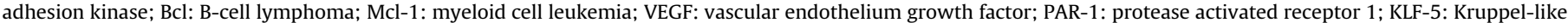
factor 5; PLX1DC: plexin domain containing 1; HIF-1a: hypoxia inducible factor 1a; CA: ceramidase acid; MDM2: murine double minute 2; POSTN: periostin.

${ }^{a}$ Murine cell model, s.c: sub-cutaneous injection, i.p: intraperitoneal injection, i.v: intravenous injection.

receptor of ephrins that takes function in cell-cell contact and cell migration by activation of MAPK pathways promoting oncogenesis and increased expression has been detected in numerous cancers [108]. Inhibitions by RNAi technology proved the anti-cancer potential of in vitro targeting and local in vivo treatment respectively in malignant mesothelioma and squamous carcinoma [109,110]. One study exposed some results on intravenous injection of mineral nanoparticles loaded with EphA2 siRNA [57]. A single injection, two weeks after cell inoculation, was sufficient to lead to a $55 \%$ decrease of tumoral volume.
Numerous cancers, as for example skin cancer [111] and prostate cancer [112] have shown disregulation of PI3K/AKT pathways. Many reviews have described oncogenic overexpression of AKT and its roles in chemoresistance [113]. SiRNA knock down of three different AKT isoforms was explored by Sasaki et al., in prostate cancer model [114]. Atelocollagen was mixed with siRNA and injected every three days during two weeks by intravenous injections. All AKT isoforms siRNA conducted to an important regression of tumoral volume, i.e. $66 \%, 89 \%$ and $57 \%$ for respectively AKT1, AKT2 and AKT3 isoforms [114]. 
Then, the PKN3 protein, named also PKN $\beta$, has been identified a few years ago [115]. Leenders et al., demonstrated their interaction with PI3K/AKT pathways and their antiproliferative effect on prostate cell by shRNA extinction [116]. In vivo inhibition strategy was realized with siRNA liposomal form [117]. Repetitive intravenous injections were realized on mice bearing organotypic prostate tumor and provided $60 \%$ of tumoral volume inhibition. Moreover, metastatic process was highly inhibited with $75 \%$ of metastasis number reduction [117].

Increased focal adhesion kinase [57] levels were reported in prostate [118], and breast [119] as well as in glioma [120]. FAK can be activated by integrins and is involved in multiple pathways controlling proliferation, survival, cell migration and anoikis resistance [121]. Its overexpression has been correlated with increased invasion and migration of several metastatic tumor types [122]. Inhibition of FAK protein has been obtained by different strategies: competitive molecule (FIP200); tyrosine kinase inhibitors (TKI) (PF-228) or RNAi (siRNA) [123]. Chemical inhibitors led to the regression of tumoral volume as demonstrated by Roberts et al. [124]. Delivery systems based on chitosan nanoparticles loaded with FAK siRNA, were developed for systemic treatment [31]. Twice weekly injections of $4 \mu \mathrm{g}$ siRNA allowed inhibiting 60\% of human ovarian tumor growth in nude mice.

\subsection{Cell death and survival}

Pathways involved in cell death and survival have important role in cancer development [125]. Cancer cells display acquired or innate cell death resistance mechanisms (to apoptosis or other cell death pathways). Apoptosis regulation pathways form a very complex molecular network with the two intrinsic and extrinsic classically recognized triggering pathways [126]. Bcl-2 family proteins are major molecular regulators of mitochondrial pathway leading to apoptosis and clearly related with cancer progression [127]. Antiapoptotic bcl-2 family members as Bcl-2, Bcl-xL and Mcl-1, have been shown to be overexpressed in cancer pathologies including leukemia [128] and myeloma [129]. Then, poor survival was also associated with these Bcl-2 members' up-regulation in hepatocarcinoma [130]. Moreover, chemotherapy resistance was early associated with $\mathrm{Bcl}-2$ and $\mathrm{Bcl}-\mathrm{xL}$ high level expression, respectively in gastric and breast cancer [131,132]. Intravenous injections of vectorized siRNA targeting these three molecules were evaluated in tumor bearing mice: $\mathrm{Bcl}-2$ and $\mathrm{Mcl}-1$ siRNA in pegylated cationic liposomes [27,55], and Bcl-xL siRNA complexed with atelocollagen [48]. In these studies, reduction of tumor growth reached $40 \%-65 \%$. Abnormal expression or overexpression of inhibitor of apoptosis proteins (IAPs) as survivin that has been correlated with oncogenic progression was reported in hepatocellular carcinoma [133], lung cancer [134], and ovarian cancer [135]. In addition, numerous studies have evidenced higher survivin expression during metastasis development, such as in prostate cancer [136] and in poor prognosis in meningioma [137]. Different survivin inhibition strategies resulted in marked antiproliferative effects in endometrial and breast animal cancer models [138,139]. Solid lipid-PEI nanocarriers were developed by Xue et al., to carry survivin siRNA [14]. A low dose of siRNA, only $14 \mu \mathrm{g}$ delivered in twice injections, was sufficient to obtain $30 \%$ of tumoral volume regression.

\subsection{Angiogenesis}

Angiogenesis is an essential step for cancer development and has thus been recognized as a hallmark of cancers [125]. Without angiogenesis, cancer could not grow up to more than $2 \mathrm{~mm}$ of diameter as firstly emphasized by J Folkman. In this way, stopping neoangiogenic mechanism could constitute a key strategy to inhibit tumor growth [140]. However, numerous inhibitors have already been developed to slow down angiogenesis such as antibodies and TKI (sunitinib ${ }^{\circledR}$, sorafenib ${ }^{\circledR}$, axitinib ${ }^{\circledR}$, and pazopanib ${ }^{\circledR}$ ) but with appearance of resistance siRNA could therefore provide an alternative strategy [141,142]. Vascular endothelium growth factors (VEGFs and VEGFA in particular) are the most described secreted molecules implicated in angiogenesis of human cancers [143]. PolyL-lysine nanocarriers of VEGF siRNA administered intravenously reduced by $53 \%$ prostate sub-cutaneous tumors [25] while VEGF siRNA micelles led to $87 \%$ volume reduction [144].

As controversies on the benefits of such anti-angiogenic therapies arose recently, other angiogenic factors or markers could be interesting alternatives like protease activated receptor 1 (PAR-1) which is enrolled in thrombin regulation and whose expression is correlated with angiogenesis in many cancer types [145] or platelet endothelial cell adhesion molecule 1 (PECAM-1 or CD31) [146]. Both have been targeted in vivo by siRNA in melanoma and prostate cancer models respectively. Reduction in tumor size and metastases has been obtained [147]. Finally, plexin domain containing 1 (PLXDC1) or TEM7 (tumor endothelial marker 7) is a protein showing an overexpression in cancerous endothelium [148] and a correlation with metastasis and poor prognosis [149]. Chitosan nanoparticles were used to carry PLXDC1 siRNA in orthotopic mice ovarian cancer model [31]. Low final dose of siRNA (maximal $30 \mu \mathrm{g}$ ) injected in 10 times was sufficient to produce a strong blockage of tumoral growth with $87 \%$ of volume inhibition.

\subsection{Other pathways}

Hypoxia triggers angiogenesis via several cellular mediators including the well-known HIF-1 $\alpha$ transcription factor. Wang et al., developed multi-functional peptide-based carrier to deliver antiHIF- $1 \propto$ RNA that inhibited by $50 \%$ glioma tumor growth [30].

Kruppel-like factor 5 (KLF-5) is a transcriptional factor implicated in the epithelial cell proliferation and consequently in angiogenesis [150]. This protein was targeted by siRNA carried by wrapped liposomes in two sub-cutaneous cancerous models [53]. A total siRNA dose of $350 \mu \mathrm{g}$ was injected intravenously in murine lung carcinoma and a $60 \%$ of volume reduction was obtained. Prostate model was also assessed in a KLF-5 inhibition therapy [53]. Ten injections of $150 \mu \mathrm{g}$ siRNA were performed and decreased the tumoral volume to $48 \%$. Moreover, this inhibition demonstrated their efficacy to prolong the survival median.

Furthermore, nucleo-cytoplasmic transport for signaling molecules and transcription factors is controlled by protein complexes situated at nucleus pore, including importin $\alpha$ and importin $\beta$. Ran GTPase is also implicated in this transport regulation and can contribute to pathways of cell transformation facilitating tumor progression [151]. Inhibition of Ran was assessed in sub-cutaneous murine neuroblastoma and resulted in $49 \%$ of tumoral volume regression with a single low dose of siRNA $(150 \mu \mathrm{g})$ [29].

Considering the hallmarks of cancers as defined by Hanahan and Weinberg, bioenergetic metabolism is attractive for new therapies. Example is provided with the acid ceramidase (AC) that plays a key role in cancer development through the enhanced conversion of ceramide into the anti-apoptotic shingosine 1-phosphate [152]. A breast cancer mice model was developed to evaluate the effect of AC siRNA inhibition [63]. Results showed a strong inhibition with $75 \%$ of tumoral volume regression by using $240 \mu \mathrm{g}$ of siRNA.

RecQL1, a human helicase, participates in DNA repair and the maintenance of genome integrity. This protein is highly upregulated in rapidly growing cells including various kinds of cancers [153]. Pancreatic, lung and colorectal cancer models in mouse have been treated respectively by intravenous injections of 250 , 400 , and $500 \mu \mathrm{g}$ of RecQL1 siRNA entrapped into non-viral delivery 
systems [154]. These protocols induced alone $31 \%, 43 \%$ and $46 \%$ of tumor growth inhibition for pancreatic, colorectal and lung cancers. Finally, resistance mechanisms to chemotherapy include the overexpression of $A B C$ efflux pumps such as P-glycoprotein (P-gp) that decrease intracellular chemotherapeutic agents like doxorubicin [155]. Jiang et al., worked on the effect of P-gp siRNA on doxorubicin resistant human breast cancer cells [39]. After treatment with P-gp siRNA liposomes, tumoral volumes were reduced to $63 \%$ vs doxorubicin alone (28\%).

\subsection{Virus and fusion oncogenes}

As several cancer types can be induced by oncogenes from viruses, specific strategies can be developed to combat them. Examples are E6 and E7 oncogenes of human papilloma virus (HPV) that have been inhibited by siRNA strategy in murine sub-cutaneous renal carcinoma models [7] resulting in 55\% of tumoral progression blockage and prolonged survival median in a metastatic model.

Genetic changes as chromosome rearrangement can cause the synthesis of abnormal fusion proteins. These later can turn out to be oncogenic and then favor the proliferation and progression of tumors. The ret/PTC1 fusion protein appears as a specific oncogene rearrangement presented in thyroid cancers [156]. de Martimprey et al., developed a siRNA strategy on ret/PTC1 protein [157]. These chitosan nanoparticles were able to strongly reduce the tumor size with $90 \%$ of volume reduction. EWS-FLI1 is another chimeric gene produced by abnormal chromosomal rearrangement, associated with Ewing sarcoma and targeted to develop a new therapeutic treatment $[158,159]$. The inhibition of EWS-FLI1 by siRNA was conducted by Hu-Lieskovan and coworkers [70]. Cyclodextrin based nanoparticles were injected 8 times until total siRNA dose of $400 \mu \mathrm{g}$ and proved an effective inhibition of tumoral progression with $80 \%$ of tumoral volume reduction. Finally, targeting of SS18-SSX, a fusion protein [160], described in synovial sarcoma by a consistent chromosome translocation (X; 18) was tested by Takenaka et al., in wrapped liposomes with repetitive intravenous injections. Their protocol allowed a strong volume diminution estimated at 83\% [52].

\section{Perspectives}

\subsection{RNAi in clinics: introduction}

To date, very few nucleotide-based drugs reached the market. The first one was an antisense oligonucleotide from Isis Pharmaceuticals in 1998 to treat CMV retinitis (Formivirsen; Vitravene ${ }^{\circledR}$ ) but the company stopped it because of its very limited market. This drug is the first proof that local delivery of RNAi-based treatment can be envisaged. The aptamer Pegaptanib (Macugen ${ }^{\circledR}$ ) is the second example of nucleotide-based therapy approved by the FDA in 2004 for the acute macular degenerescence (AMD) with local administration.

Despite more than 60 clinical trials conducted with antisense oligonucleotides to combat cancer (clinicaltrials.gov) and 589 publications in pubmed database on "oligonucleotide and cancer" in "clinical trials", (April 2013), no one reached the market. Among the most promising ones, anti-Bcl-2 antisense (Oblimersen ${ }^{\circledR}$ ) did not get FDA approval after the phase III randomized trial for chronic lymphocytic leukemia [161] because of lack of efficacy in terms of intent-to-treat survival benefits. Great hope has been placed in siRNA that emerges now in clinical trials as detailed hereafter.

\subsection{Clinical trials}

Pubmed references 31 publications related to "siRNA and cancer" in "clinical trials" (April 2013) but only few clinical trials (all in phase I clinical status) are listed on clinicaltrials.gov for solid tumor treatment. CALAA-01 is an siRNA that reduced the expression of the M2 ribonucleotide reductase subunit (R2) and was shown to inhibit/reduce melanoma tumor growth in vivo in mice [162]. The CALAA-01 siRNA was protected from nuclease degradation within stabilized cyclodextrin-based nanoparticles targeted to tumor cells via transferrin [163]. These nanoparticles were injected intravenously in three patients and proved effective against tumor tissues [164]. Nowadays, the Phase I trial is in progress on the safety and the adapted dose of these siRNA nanoparticles.

A second non-viral siRNA delivery system, Atu027, is in its prospective phase of clinical trials. As described before, this nanoscale system has proved its in vitro and in vivo efficacy [117,147]. Moreover, these liposomes loaded with a PKN3 siRNA were injected intravenously for $4 \mathrm{~h}$ in a single dose in 24 human patients. The first results showed the good tolerance to Atu027 by patients [165]. Further studies will be conducted to determine the siRNA efficacy in terms of anti-cancer effects.

Phase I trial with a liposome-carried EphA2 siRNA associated with promising results in mice [57] has just started recruitment in summer 2012. A dose of $450 \mu \mathrm{g} / \mathrm{m}^{2}$ of siRNA into nanomedicines will be injected intravenously twice weekly during 3 week cycles in patients diagnosed with ovarian cancer. The aim of Phase I will be the study of the safety of these siRNA-EphA2-DOPC and their maximal tolerated dose (MTD).

While these clinical trials were inconceivable ten years ago, they are nowadays ongoing and showing good tolerance levels with no evidence of side effects. Also encouraging results obtained with concomitant treatment in cancer have thus suggested the possibility to undertake personalized treatment in the future (early stage diagnosis, tumor screening, siRNA pool specific for the patient...).

\subsection{Concomitant treatments}

The transitory effects of siRNA are adapted to chronic disease [166] however, concomitant treatments allowed by the use of synthetic delivery systems (different siRNA, chemo and radiotherapy...) are necessary. The poor results obtained with single siRNA delivery have encouraged the development of concomitant strategies by combining several siRNA to target simultaneously different pathways or to use single siRNA with other therapeutic agents. For example, three siRNA were co-formulated in liposomes by Huang et al. [8,64]. These siRNA targeted MDM2, c-myc and VEGF proteins that were all implicated in the development of cancerous pathologies. Two intravenous injections of $9 \mu \mathrm{g}$ siRNA were able to produce $30 \%$ volume regression in a mouse melanoma metastasis model [64]. Moreover, double doses of siRNA increased the survival median by 6 days corresponding to 30\% compared to the control group in the same cancer model [8].

Association and synergy between siRNA and other drugs could potentially improve their therapeutic effect. SiRNA delivery systems have been already tested in association with classic chemotherapeutic agents. Multifunctional nanoparticles, transporting siRNA and doxorubicin, were developed by Chen et al., to demonstrate their effect $[65,68]$. A colon cancer model was used to test this concomitant treatment based on doxorubicin and c-myc siRNA. While siRNA or doxorubicin treatment alone led respectively to $35 \%$ and $8 \%$ of inhibition contrary to siRNA associated with doxorubicin that led to a $60 \%$ synergic volume regression [65]. Similar results were obtained in a second study conducted with different siRNA against c-myc and VEGF with or without chemotherapy [68].

Other chemotherapeutic agents have been tested in such combination, e.g. docetaxel with periostin (POSTN) siRNA entrapped into chitosan nanoparticles [31]. Periostin plays a significant role in cell invasion, survival, and angiogenesis, leading to metastasis 
[167]. In an ovarian cancer model, injections of POSTN siRNA with docetaxel increased tumoral regression (90\% reduction in comparison to $70 \%$ and $50 \%$ regression when siRNA or docetaxel was used alone) and decreased also significantly the number of tumoral nodules [31].

\section{Acknowledgments}

We would like to thank the foundation "Association de Recherche contre le Cancer" and "La Ligue contre le cancer 49 et 35", "Conseil Régional de Bretagne", the "Structure Fédératif de Recherche de Brest" (SFR 148 ScInBioS), "Association Française contre les Myopathies" (AFM, Evry, France), "Vaincre La Mucoviscidose" (Paris, France), and "Association de transfusion sanguine et de biogénétique Gaétan Saleün” (Brest, France).

\section{References}

[1] Ratcliff F, Harrison BD, Baulcombe DC. A similarity between viral defense and gene silencing in plants. Science 1997;276:1558-60.

[2] Fire A, Xu S, Montgomery MK, Kostas SA, Driver SE, Mello CC. Potent and specific genetic interference by double-stranded RNA in Caenorhabditis elegans. Nature 1998;391:806-11.

[3] Winter J, Jung S, Keller S, Gregory RI, Diederichs S. Many roads to maturity: microRNA biogenesis pathways and their regulation. Nat Cell Biol 2009;11: 228-34.

[4] Pushparaj PN, Aarthi JJ, Manikandan J, Kumar SD. siRNA, miRNA, and shRNA: in vivo applications. J Dent Res 2008;87:992-1003.

[5] de Martimprey H, Vauthier C, Malvy C, Couvreur P. Polymer nanocarriers for the delivery of small fragments of nucleic acids: oligonucleotides and siRNA. Eur J Pharm Biopharm 2009;71:490-504.

[6] David S, Pitard B, Benoit JP, Passirani C. Non-viral nanosystems for systemic siRNA delivery. Pharmacol Res 62:100-14.

[7] Wu SY, Singhania A, Burgess M, Putral LN, Kirkpatrick C, Davies NM, et al. Systemic delivery of E6/7 siRNA using novel lipidic particles and its application with cisplatin in cervical cancer mouse models. Gene Ther 2011;18: 14-22.

[8] Li SD, Chono S, Huang L. Efficient oncogene silencing and metastasis inhibition via systemic delivery of siRNA. Mol Ther 2008;16:942-6.

[9] Tagami T, Suzuki T, Matsunaga M, Nakamura K, Moriyoshi N, Ishida T, et al. Anti-angiogenic therapy via cationic liposome-mediated systemic siRNA delivery. Int J Pharm 2012;422:280-9.

[10] Gao J, Sun J, Li H, Liu W, Zhang Y, Li B, et al. Lyophilized HER2-specific PEGylated immunoliposomes for active siRNA gene silencing. Biomaterials 2010;31:2655-64.

[11] Li J, Chen YC, Tseng YC, Mozumdar S, Huang L. Biodegradable calcium phosphate nanoparticle with lipid coating for systemic siRNA delivery. J Control Release 2010;142:416-21.

[12] Pittella F, Zhang M, Lee Y, Kim HJ, Tockary T, Osada K, et al. Enhanced endosomal escape of siRNA-incorporating hybrid nanoparticles from calcium phosphate and PEG-block charge-conversional polymer for efficient gene knockdown with negligible cytotoxicity. Biomaterials 2011;32: 3106-14.

[13] David S, Resnier P, Guillot A, Pitard B, Benoit JP, Passirani C. siRNA LNCs - a novel platform of lipid nanocapsules for systemic siRNA administration. Eur J Pharm Biopharm 2012;81:448-52.

[14] Xue HY, Wong HL. Solid lipid-PEI hybrid nanocarrier: an integrated approach to provide extended, targeted, and safer siRNA therapy of prostate cancer in an all-in-one manner. ACS Nano 2011;5:7034-47.

[15] Shahzad MM, Mangala LS, Han HD, Lu C, Bottsford-Miller J, Nishimura M, et al. Targeted delivery of small interfering RNA using reconstituted highdensity lipoprotein nanoparticles. Neoplasia 2011;13:309-19.

[16] Susa M, Iyer AK, Ryu K, Choy E, Hornicek FJ, Mankin H, et al. Inhibition of ABCB1 (MDR1) expression by an siRNA nanoparticulate delivery system to overcome drug resistance in osteosarcoma. PLoS One 2010;5:e10764.

[17] de Martimprey H, Bertrand JR, Malvy C, Couvreur P, Vauthier C. New coreshell nanoparticules for the intravenous delivery of siRNA to experimental thyroid papillary carcinoma. Pharm Res 2010;27:498-509.

[18] Yang XZ, Dou S, Sun TM, Mao CQ, Wang HX, Wang J. Systemic delivery of siRNA with cationic lipid assisted PEG-PLA nanoparticles for cancer therapy. J Control Release 2011;156:203-11.

[19] Huh MS, Lee SY, Park S, Lee S, Chung H, Choi Y, et al. Tumor-homing glycol chitosan/polyethylenimine nanoparticles for the systemic delivery of siRNA in tumor-bearing mice. J Control Release 2010;144:134-43.

[20] Abbasi S, Paul A, Prakash S. Investigation of siRNA-loaded polyethyleniminecoated human serum albumin nanoparticle complexes for the treatment of breast cancer. Cell Biochem Biophys 2011;61:277-87.

[21] Palanca-Wessels MC, Convertine AJ, Cutler-Strom R, Booth GC, Lee F, Berguig GY, et al. Anti-CD22 antibody targeting of pH-responsive micelles enhances small interfering RNA delivery and gene silencing in lymphoma cells. Mol Ther 2011;19:1529-37.

[22] Kim HJ, Oba M, Pittella F, Nomoto T, Cabral H, Matsumoto Y, et al. PEG detachable cationic polyaspartamide derivatives bearing stearoyl moieties for systemic siRNA delivery toward subcutaneous BxPC3 pancreatic tumor. J Drug Target 2012;20:33-42.

[23] Xiong XB, Lavasanifar A. Traceable multifunctional micellar nanocarriers for cancer-targeted co-delivery of MDR-1 siRNA and doxorubicin. ACS Nano 2011;5:5202-13.

[24] Hillaireau H, Couvreur P. Nanocarriers' entry into the cell: relevance to drug delivery. Cell Mol Life Sci 2009;66:2873-96.

[25] Guo J, Cheng WP, Gu J, Ding C, Qu X, Yang Z, et al. Systemic delivery of therapeutic small interfering RNA using a pH-triggered amphiphilic poly-llysine nanocarrier to suppress prostate cancer growth in mice. Eur J Pharm Sci 2011.

[26] Sakurai Y, Hatakeyama H, Sato Y, Akita H, Takayama K, Kobayashi S, et al. Endosomal escape and the knockdown efficiency of liposomal-siRNA by the fusogenic peptide shGALA. Biomaterials 2011;32:5733-42.

[27] Shim G, Han SE, Yu YH, Lee S, Lee HY, Kim K, et al. Trilysinoyl oleylamidebased cationic liposomes for systemic co-delivery of siRNA and an anticancer drug. J Control Release 2011;155:60-6.

[28] Sun TM, Du JZ, Yao YD, Mao CQ, Dou S, Huang SY, et al. Simultaneous delivery of siRNA and paclitaxel via a "two-in-one" micelleplex promotes synergistic tumor suppression. ACS Nano 2011;5:1483-94.

[29] Tietze N, Pelisek J, Philipp A, Roedl W, Merdan T, Tarcha P, et al. Induction of apoptosis in murine neuroblastoma by systemic delivery of transferrinshielded siRNA polyplexes for downregulation of Ran. Oligonucleotides 2008; $18: 161-74$

[30] Wang XL, Xu R, Wu X, Gillespie D, Jensen R, Lu ZR. Targeted systemic delivery of a therapeutic siRNA with a multifunctional carrier controls tumor proliferation in mice. Mol Pharm 2009;6:738-46.

[31] Han HD, Mangala LS, Lee JW, Shahzad MM, Kim HS, Shen D, et al. Targeted gene silencing using RGD-labeled chitosan nanoparticles. Clin Cancer Res 2010;16:3910-22.

[32] Meier R, Henning TD, Boddington S, Tavri S, Arora S, Piontek G, et al. Breast cancers: MR imaging of folate-receptor expression with the folate-specific nanoparticle P1133. Radiology 2010;255:527-35.

[33] Varkouhi AK, Scholte M, Storm G, Haisma HJ. Endosomal escape pathways for delivery of biologicals. J Control Release 2011;151:220-8.

[34] Wasungu L, Hoekstra D. Cationic lipids, lipoplexes and intracellular delivery of genes. J Control Release 2006;116:255-64.

[35] Wang XL, Ramusovic S, Nguyen T, Lu ZR. Novel polymerizable surfactants with $\mathrm{pH}$-sensitive amphiphilicity and cell membrane disruption for efficient siRNA delivery. Bioconjug Chem 2007:18:2169-77.

[36] Felber AE, Castagner B, Elsabahy M, Deleavey GF, Damha MJ, Leroux JC. siRNA nanocarriers based on methacrylic acid copolymers. J Control Release 2011;152:159-67.

[37] Yessine MA, Lafleur M, Meier C, Petereit HU, Leroux JC. Characterization of the membrane-destabilizing properties of different $\mathrm{pH}$-sensitive methacrylic acid copolymers. Biochim Biophys Acta 2003;1613:28-38.

[38] Morille M, Passirani C, Vonarbourg A, Clavreul A, Benoit JP. Progress in developing cationic vectors for non-viral systemic gene therapy against cancer. Biomaterials 2008;29:3477-96.

[39] Jiang J, Yang SJ, Wang JC, Yang LJ, Xu ZZ, Yang T, et al. Sequential treatment of drug-resistant tumors with RGD-modified liposomes containing siRNA or doxorubicin. Eur J Pharm Biopharm 2010;76:170-8.

[40] Cardarelli F, Pozzi D, Bifone A, Marchini C, Caracciolo G. Cholesteroldependent macropinocytosis and endosomal escape control the transfection efficiency of lipoplexes in CHO living cells. Mol Pharm 2012.

[41] Fang N, Wang J, Mao H-Q, Leong KW, Chan V. BHEM-Chol/DOPE liposome induced perturbation of phospholipid bilayer. Colloids Surf B Biointerfaces 2003:29:233-45.

[42] Miyata K, Oba M, Nakanishi M, Fukushima S, Yamasaki Y, Koyama H, et al. Polyplexes from poly(aspartamide) bearing 1,2-diaminoethane side chains induce $\mathrm{pH}$-selective, endosomal membrane destabilization with amplified transfection and negligible cytotoxicity. J Am Chem Soc 2008;130:16287-94.

[43] Canine BF, Wang Y, Ouyang W, Hatefi A. Development of targeted recombinant polymers that can deliver siRNA to the cytoplasm and plasmid DNA to the cell nucleus. J Control Release 2011;151:95-101.

[44] Kawakami S, Hashida M. Targeted delivery systems of small interfering RNA by systemic administration. Drug Metab Pharmacokinet 2007;22:142-51.

[45] White PJ. Barriers to successful delivery of short interfering RNA after systemic administration. Clin Exp Pharmacol Physiol 2008;35:1371-6.

[46] Grzelinski M, Urban-Klein B, Martens T, Lamszus K, Bakowsky U, Hobel S et al. RNA interference-mediated gene silencing of pleiotrophin through polyethylenimine-complexed small interfering RNAs in vivo exerts antitumoral effects in glioblastoma xenografts. Hum Gene Ther 2006;17:751-66.

[47] Hobel S, Koburger I, John M, Czubayko F, Hadwiger P, Vornlocher HP, et al. Polyethylenimine/small interfering RNA-mediated knockdown of vascular endothelial growth factor in vivo exerts anti-tumor effects synergistically with bevacizumab. J Gene Med 2010;12:287-300.

[48] Mu P, Nagahara S, Makita N, Tarumi Y, Kadomatsu K, Takei Y. Systemic delivery of siRNA specific to tumor mediated by atelocollagen: combined therapy using siRNA targeting Bcl-xL and cisplatin against prostate cancer. Int J Cancer 2009;125:2978-90. 
[49] Werth S, Urban-Klein B, Dai L, Hobel S, Grzelinski M, Bakowsky U, et al. A low molecular weight fraction of polyethylenimine (PEI) displays increased transfection efficiency of DNA and siRNA in fresh or lyophilized complexes. J Control Release 2006;112:257-70.

[50] Montazeri Aliabadi H, Landry B, Mahdipoor P, Uludag H. Induction of apoptosis by survivin silencing through siRNA delivery in a human breast cancer cell line. Mol Pharm 2011;8:1821-30.

[51] Crombez L, Morris MC, Dufort S, Aldrian-Herrada G, Nguyen Q, Mc Master G, et al. Targeting cyclin B1 through peptide-based delivery of siRNA prevents tumour growth. Nucleic Acids Res 2009;37:4559-69.

[52] Takenaka S, Naka N, Araki N, Hashimoto N, Ueda T, Yoshioka K, et al Downregulation of SS18-SSX1 expression in synovial sarcoma by smal interfering RNA enhances the focal adhesion pathway and inhibits anchorage-independent growth in vitro and tumor growth in vivo. Int J Oncol 2010;36:823-31.

[53] Yagi N, Manabe I, Tottori T, Ishihara A, Ogata F, Kim JH, et al. A nanoparticle system specifically designed to deliver short interfering RNA inhibits tumor growth in vivo. Cancer Res 2009;69:6531-8.

[54] Wu SY, Putral LN, Liang M, Chang HI, Davies NM, McMillan NA. Development of a novel method for formulating stable siRNA-loaded lipid particles for in vivo use. Pharm Res 2009;26:512-22.

[55] Sonoke S, Ueda T, Fujiwara K, Sato Y, Takagaki K, Hirabayashi K, et al. Tumor regression in mice by delivery of Bcl-2 small interfering RNA with pegylated cationic liposomes. Cancer Res 2008;68:8843-51.

[56] Bartlett DW, Davis ME. Physicochemical and biological characterization of targeted, nucleic acid-containing nanoparticles. Bioconjug Chem 2007;18: 456-68.

[57] Tanaka T, Mangala LS, Vivas-Mejia PE, Nieves-Alicea R, Mann AP, Mora E, et al. Sustained small interfering RNA delivery by mesoporous silicon particles. Cancer Res 2010;70:3687-96.

[58] Taratula O, Garbuzenko OB, Kirkpatrick P, Pandya I, Savla R, Pozharov VP, et al. Surface-engineered targeted PPI dendrimer for efficient intracellular and intratumoral siRNA delivery. J Control Release 2009;140:284-93.

[59] Halma C, Daha MR, van Es LA. In vivo clearance by the mononuclear phagocyte system in humans: an overview of methods and their interpretation. Clin Exp Immunol 1992;89:1-7.

[60] Meerasa A, Huang JG, Gu FX. CH(50): a revisited hemolytic complement consumption assay for evaluation of nanoparticles and blood plasma protein interaction. Curr Drug Deliv 2011;8:290-8.

[61] Boraschi D, Costantino L, Italiani P. Interaction of nanoparticles with immunocompetent cells: nanosafety considerations. Nanomedicine (Lond) 2012;7:121-31

[62] Vonarbourg A, Saulnier P, Passirani C, Benoit JP. Electrokinetic properties of noncharged lipid nanocapsules: influence of the dipolar distribution at the interface. Electrophoresis 2005;26:2066-75.

[63] Mao CQ, Du JZ, Sun TM, Yao YD, Zhang PZ, Song EW, et al. A biodegradable amphiphilic and cationic triblock copolymer for the delivery of siRNA targeting the acid ceramidase gene for cancer therapy. Biomaterials 2011;32: 3124-33.

[64] Chen Y, Zhu X, Zhang X, Liu B, Huang L. Nanoparticles modified with tumortargeting scFv deliver siRNA and miRNA for cancer therapy. Mol Ther 2010;18:1650-6.

[65] Chen Y, Wu JJ, Huang L. Nanoparticles targeted with NGR motif deliver c-myc siRNA and doxorubicin for anticancer therapy. Mol Ther 2010;18:828-34.

[66] Maeda H, Wu J, Sawa T, Matsumura Y, Hori K. Tumor vascular permeability and the EPR effect in macromolecular therapeutics: a review. J Control Release 2000;65:271-84.

[67] Halder J, Kamat AA, Landen Jr CN, Han LY, Lutgendorf SK, Lin YG, et al. Focal adhesion kinase targeting using in vivo short interfering RNA delivery in neutral liposomes for ovarian carcinoma therapy. Clin Cancer Res 2006;12: 4916-24.

[68] Chen Y, Bathula SR, Li J, Huang L. Multifunctional nanoparticles delivering small interfering RNA and doxorubicin overcome drug resistance in cancer. J Biol Chem 2010;285:22639-50.

[69] Kaestner P, Aigner A, Bastians H. Therapeutic targeting of the mitotic spindle checkpoint through nanoparticle-mediated siRNA delivery inhibits tumo growth in vivo. Cancer Lett 2011;304:128-36.

[70] Hu-Lieskovan S, Heidel JD, Bartlett DW, Davis ME, Triche TJ. Sequence-specific knockdown of EWS-FLI1 by targeted, nonviral delivery of small interfering RNA inhibits tumor growth in a murine model of metastatic Ewing's sarcoma. Cancer Res 2005;65:8984-92.

[71] Pasqualini R, Koivunen E, Ruoslahti E. Alpha v integrins as receptors for tumor targeting by circulating ligands. Nat Biotechnol 1997;15:542-6.

[72] Corti A, Curnis F, Arap W, Pasqualini R. The neovasculature homing motif NGR: more than meets the eye. Blood 2008;112:2628-35.

[73] Hashida $\mathrm{H}$, Takabayashi A, Kanai M, Adachi M, Kondo K, Kohno N, et al. Aminopeptidase $\mathrm{N}$ is involved in cell motility and angiogenesis: its clinical significance in human colon cancer. Gastroenterology 2002;122: 376-86.

[74] Oku N, Asai T, Watanabe K, Kuromi K, Nagatsuka M, Kurohane K, et al. Antineovascular therapy using novel peptides homing to angiogenic vessels. Oncogene 2002;21:2662-9.

[75] Maeda N, Takeuchi Y, Takada M, Namba Y, Oku N. Synthesis of angiogenesistargeted peptide and hydrophobized polyethylene glycol conjugate. Bioorg Med Chem Lett 2004;14:1015-7.
[76] Asai T, Matsushita S, Kenjo E, Tsuzuku T, Yonenaga N, Koide H, et al. Dicetyl phosphate-tetraethylenepentamine-based liposomes for systemic siRNA delivery. Bioconjug Chem 2011;22:429-35.

[77] Harrison GS, Wierman ME, Nett TM, Glode LM. Gonadotropin-releasing hormone and its receptor in normal and malignant cells. Endocr Relat Cancer 2004; $11: 725-48$

[78] Liu SV, Liu S, Pinski J. Luteinizing hormone-releasing hormone receptor targeted agents for prostate cancer. Expert Opin Investig Drugs 2011;20: 769-78.

[79] Jaracz S, Chen J, Kuznetsova LV, Ojima I. Recent advances in tumor-targeting anticancer drug conjugates. Bioorg Med Chem 2005;13:5043-54.

[80] Toole BP, Hascall VC. Hyaluronan and tumor growth. Am J Pathol 2002;161: 745-7.

[81] Toole BP. Hyaluronan promotes the malignant phenotype. Glycobiology 2002; $12: 37 R-42 R$.

[82] Toole BP. Hyaluronan-CD44 interactions in cancer: paradoxes and possibilities. Clin Cancer Res 2009;15:7462-8.

[83] Daniels TR, Delgado T, Helguera G, Penichet ML. The transferrin receptor part II: targeted delivery of therapeutic agents into cancer cells. Clin Immunol 2006:121:159-76.

[84] Daniels TR, Delgado T, Rodriguez JA, Helguera G, Penichet ML. The transferrin receptor part I: biology and targeting with cytotoxic antibodies for the treatment of cancer. Clin Immunol 2006;121:144-58.

[85] Pirollo KF, Zon G, Rait A, Zhou Q, Yu W, Hogrefe R, et al. Tumor-targeting nanoimmunoliposome complex for short interfering RNA delivery. Hum Gene Ther 2006;17:117-24.

[86] Hartwell LH, Weinert TA. Checkpoints: controls that ensure the order of cell cycle events. Science 1989;246:629-34.

[87] Donjerkovic D, Scott DW. Regulation of the G1 phase of the mammalian cell cycle. Cell Res 2000;10:1-16.

[88] Nozoe T, Korenaga D, Kabashima A, Ohga T, Saeki H, Sugimachi K. Significance of cyclin B1 expression as an independent prognostic indicator of patients with squamous cell carcinoma of the esophagus. Clin Cancer Res 2002;8:817-22.

[89] Soria JC, Jang SJ, Khuri FR, Hassan K, Liu D, Hong WK, et al. Overexpression of cyclin B1 in early-stage non-small cell lung cancer and its clinical implication. Cancer Res 2000;60:4000-4.

[90] Ikuerowo SO, Kuczyk MA, Mengel M, van der Heyde E, Shittu OB, Vaske B, et al. Alteration of subcellular and cellular expression patterns of cyclin B1 in renal cell carcinoma is significantly related to clinical progression and survival of patients. Int J Cancer 2006;119:867-74.

[91] Kallakury BV, Sheehan CE, Rhee SJ, Fisher HA, Kaufman Jr RP, Rifkin MD, et al. The prognostic significance of proliferation-associated nucleolar protein p120 expression in prostate adenocarcinoma: a comparison with cyclins A and B1, Ki-67, proliferating cell nuclear antigen, and p34cdc2. Cancer 1999;85:1569-76.

[92] Strebhardt K, Ullrich A. Targeting polo-like kinase 1 for cancer therapy. Nat Rev Cancer 2006;6:321-30.

[93] Kneisel L, Strebhardt K, Bernd A, Wolter M, Binder A, Kaufmann R. Expression of polo-like kinase (PLK1) in thin melanomas: a novel marker of metastatic disease. J Cutan Pathol 2002;29:354-8.

[94] Wolf G, Elez R, Doermer A, Holtrich U, Ackermann H, Stutte HJ, et al. Prognostic significance of polo-like kinase (PLK) expression in non-small cell lung cancer. Oncogene 1997;14:543-9.

[95] Takahashi T, Sano B, Nagata T, Kato H, Sugiyama Y, Kunieda K, et al. Polo-like kinase 1 (PLK1) is overexpressed in primary colorectal cancers. Cancer Sci 2003;94:148-52.

[96] Wolf G, Hildenbrand R, Schwar C, Grobholz R, Kaufmann M, Stutte HJ, et al Polo-like kinase: a novel marker of proliferation: correlation with estrogenreceptor expression in human breast cancer. Pathol Res Pract 2000;196: 753-9.

[97] Reagan-Shaw S, Ahmad N. Silencing of polo-like kinase (Plk) 1 via siRNA causes induction of apoptosis and impairment of mitosis machinery in human prostate cancer cells: implications for the treatment of prostate cancer. FASEB J 2005;19:611-3.

[98] Gumireddy K, Reddy MV, Cosenza SC, Boominathan R, Baker SJ, Papathi N, et al. ON01910, a non-ATP-competitive small molecule inhibitor of Plk1, is a potent anticancer agent. Cancer Cell. 2005;7:275-86.

[99] Cleveland DW, Mao Y, Sullivan KF. Centromeres and kinetochores: from epigenetics to mitotic checkpoint signaling. Cell 2003;112:407-21.

[100] Mapelli M, Massimiliano L, Santaguida S, Musacchio A. The Mad2 conformational dimer: structure and implications for the spindle assembly checkpoint. Cell 2007;131:730-43.

[101] Zhang SH, Xu AM, Chen XF, Li DH, Sun MP, Wang YJ. Clinicopathologic significance of mitotic arrest defective protein 2 overexpression in hepatocellular carcinoma. Hum Pathol 2008;39:1827-34.

[102] Alizadeh AA, Eisen MB, Davis RE, Ma C, Lossos IS, Rosenwald A, et al. Distinct types of diffuse large B-cell lymphoma identified by gene expression profiling. Nature 2000;403:503-11.

[103] Kato T, Daigo Y, Aragaki M, Ishikawa K, Sato M, Kondo S, et al. Overexpression of MAD2 predicts clinical outcome in primary lung cancer patients. Lung Cancer 2011;74:124-31.

[104] Rimkus C, Friederichs J, Rosenberg R, Holzmann B, Siewert JR, Janssen KP. Expression of the mitotic checkpoint gene MAD2L2 has prognostic significance in colon cancer. Int J Cancer 2007;120:207-11. 
[105] Yu L, Guo WC, Zhao SH, Tang J, Chen JL. Mitotic arrest defective protein 2 expression abnormality and its clinicopathologic significance in human osteosarcoma. APMIS 2010;118:222-9.

[106] Johnson GL, Lapadat R. Mitogen-activated protein kinase pathways mediated by ERK, JNK, and p38 protein kinases. Science 2002;298:1911-2.

[107] Katso R, Okkenhaug K, Ahmadi K, White S, Timms J, Waterfield MD. Cellular function of phosphoinositide 3-kinases: implications for development, homeostasis, and cancer. Annu Rev Cell Dev Biol 2001;17:615-75.

[108] Pasquale EB. Eph receptors and ephrins in cancer: bidirectional signalling and beyond. Nat Rev Cancer 2010;10:165-80.

[109] Mohammed KA, Wang X, Goldberg EP, Antony VB, Nasreen N. Silencing receptor EphA2 induces apoptosis and attenuates tumor growth in malignant mesothelioma. Am J Cancer Res 2011:1:419-31.

[110] Liu Y, Yu C, Qiu Y, Huang D, Zhou X, Zhang X, et al. Downregulation of EphA2 expression suppresses the growth and metastasis in squamous-cell carcinoma of the head and neck in vitro and in vivo. J Cancer Res Clin Oncol 2012;138:195-202.

[111] Rho O, Kim DJ, Kiguchi K, Digiovanni J. Growth factor signaling pathways as targets for prevention of epithelial carcinogenesis. Mol Carcinog 2011;50: 264-79.

[112] Pommery N, Henichart JP. Involvement of PI3K/Akt pathway in prostate cancer - potential strategies for developing targeted therapies. Mini Rev Med Chem 2005;5:1125-32.

[113] McCubrey JA, Steelman LS, Abrams SL, Lee JT, Chang F, Bertrand FE, et al Roles of the RAF/MEK/ERK and PI3K/PTEN/AKT pathways in malignant transformation and drug resistance. Adv Enzyme Regul 2006;46:249-79.

[114] Sasaki T, Nakashiro K, Tanaka H, Azuma K, Goda H, Hara S, et al. Knockdown of Akt isoforms by RNA silencing suppresses the growth of human prostate cancer cells in vitro and in vivo. Biochem Biophys Res Commun 2010;399: 79-83.

[115] Mukai $\mathrm{H}$. The structure and function of PKN, a protein kinase having a catalytic domain homologous to that of PKC. J Biochem 2003;133:17-27.

[116] Leenders F, Mopert K, Schmiedeknecht A, Santel A, Czauderna F, Aleku M, et al. PKN3 is required for malignant prostate cell growth downstream of activated PI 3-kinase. EMBO J 2004;23:3303-13.

[117] Aleku M, Schulz P, Keil O, Santel A, Schaeper U, Dieckhoff B, et al. Atu027, a liposomal small interfering RNA formulation targeting protein kinase N3, inhibits cancer progression. Cancer Res 2008;68:9788-98.

[118] Lark AL, Livasy CA, Calvo B, Caskey L, Moore DT, Yang X, et al. Overexpression of focal adhesion kinase in primary colorectal carcinomas and colorectal liver metastases: immunohistochemistry and real-time PCR analyses. Clin Cancer Res 2003;9:215-22.

[119] Theocharis SE, Klijanienko JT, Padoy E, Athanassiou S, Sastre-Garau XX. Focal adhesion kinase (FAK) immunocytochemical expression in breast ductal invasive carcinoma (DIC): correlation with clinicopathological parameters and tumor proliferative capacity. Med Sci Monit 2009;15: BR221-6.

[120] Jones G, Machado Jr J, Merlo A. Loss of focal adhesion kinase (FAK) inhibits epidermal growth factor receptor-dependent migration and induces aggregation of $\mathrm{nh}(2)$-terminal FAK in the nuclei of apoptotic glioblastoma cells. Cancer Res 2001:61:4978-81.

[121] Frisch SM, Vuori K, Kelaita D, Sicks S. A role for Jun-N-terminal kinase in anoikis; suppression by bcl-2 and crmA. J Cell Biol 1996;135:1377-82.

[122] Akasaka T, van Leeuwen RL, Yoshinaga IG, Mihm Jr MC, Byers HR. Focal adhesion kinase ( $\mathrm{p} 125 \mathrm{FAK}$ ) expression correlates with motility of human melanoma cell lines. J Invest Dermatol 1995;105:104-8.

[123] Li S, Hua ZC. FAK expression regulation and therapeutic potential. Adv Cancer Res 2008;101:45-61.

[124] Roberts WG, Ung E, Whalen P, Cooper B, Hulford C, Autry C, et al. Antitumor activity and pharmacology of a selective focal adhesion kinase inhibitor, PF-562,271. Cancer Res 2008;68:1935-44.

[125] Hanahan D, Weinberg RA. Hallmarks of cancer: the next generation. Cell 2011;144:646-74

[126] Ghobrial IM, Witzig TE, Adjei AA. Targeting apoptosis pathways in cancer therapy. CA Cancer J Clin 2005;55:178-94.

[127] Reed JC. Bcl-2-family proteins and hematologic malignancies: history and future prospects. Blood 2008;111:3322-30.

[128] Shangary S, Johnson DE. Recent advances in the development of anticancer agents targeting cell death inhibitors in the Bcl-2 protein family. Leukemia 2003; $17: 1470-81$.

[129] Le Gouill S, Podar K, Amiot M, Hideshima T, Chauhan D, Ishitsuka K, et al. VEGF induces Mcl-1 up-regulation and protects multiple myeloma cells against apoptosis. Blood 2004;104:2886-92.

[130] Watanabe J, Kushihata F, Honda K, Sugita A, Tateishi N, Mominoki K, et al. Prognostic significance of Bcl-xL in human hepatocellular carcinoma. Surgery 2004; $135: 604-12$

[131] Miyake H, Hara I, Yamanaka K, Arakawa S, Kamidono S. Synergistic enhancement of resistance to cisplatin in human bladder cancer cells by overexpression of mutant-type p53 and Bcl-2. J Urol 1999;162:2176-81.

[132] Liu R, Page C, Beidler DR, Wicha MS, Nunez G. Overexpression of Bcl-x(L) promotes chemotherapy resistance of mammary tumors in a syngeneic mouse model. Am J Pathol 1999;155:1861-7.

[133] Ito T, Shiraki K, Sugimoto K, Yamanaka T, Fujikawa K, Ito M, et al. Survivin promotes cell proliferation in human hepatocellular carcinoma. Hepatology 2000;31:1080-5.
[134] Choi N, Baumann M, Flentjie M, Kellokumpu-Lehtinen P, Senan S, Zamboglou N, et al. Predictive factors in radiotherapy for non-small cell lung cancer: present status. Lung Cancer 2001;31:43-56.

[135] Sui L, Dong Y, Ohno M, Watanabe Y, Sugimoto K, Tokuda M. Survivin expression and its correlation with cell proliferation and prognosis in epithelial ovarian tumors. Int J Oncol 2002;21:315-20.

[136] Shariat SF, Lotan Y, Saboorian H, Khoddami SM, Roehrborn CG, Slawin KM, et al. Survivin expression is associated with features of biologically aggressive prostate carcinoma. Cancer 2004;100:751-7.

[137] Sasaki T, Lopes MB, Hankins GR, Helm GA. Expression of survivin, an inhibitor of apoptosis protein, in tumors of the nervous system. Acta Neuropathol 2002;104:105-9.

[138] Ai Z, Yin L, Zhou X, Zhu Y, Zhu D, Yu Y, et al. Inhibition of survivin reduces cell proliferation and induces apoptosis in human endometrial cancer. Cancer 2006;107:746-56.

139] Blanc-Brude OP, Mesri M, Wall NR, Plescia J, Dohi T, Altieri DC. Therapeutic targeting of the survivin pathway in cancer: initiation of mitochondrial apoptosis and suppression of tumor-associated angiogenesis. Clin Cancer Res 2003;9:2683-92.

[140] Ferrara N, Kerbel RS. Angiogenesis as a therapeutic target. Nature 2005;438: 967-74.

[141] Ebos JM, Lee CR, Cruz-Munoz W, Bjarnason GA, Christensen JG, Kerbel RS Accelerated metastasis after short-term treatment with a potent inhibitor of tumor angiogenesis. Cancer Cell 2009;15:232-9.

[142] Paez-Ribes M, Allen E, Hudock J, Takeda T, Okuyama H, Vinals F, et al. Antiangiogenic therapy elicits malignant progression of tumors to increased local invasion and distant metastasis. Cancer Cell. 2009;15: 220-31.

[143] Zhan P, Wang J, Lv XJ, Wang Q, Qiu LX, Lin XQ, et al. Prognostic value of vascular endothelial growth factor expression in patients with lung cancer: a systematic review with meta-analysis. J Thorac Oncol 2009;4: 1094-103.

[144] Kim SH, Jeong JH, Lee SH, Kim SW, Park TG. Local and systemic delivery of VEGF siRNA using polyelectrolyte complex micelles for effective treatment of cancer. J Control Release 2008;129:107-16.

[145] Schaffner F, Ruf W. Tissue factor and protease-activated receptor signaling in cancer. Semin Thromb Hemost 2008;34:147-53.

[146] Woodfin A, Voisin MB, Nourshargh S. PECAM-1: a multi-functional molecule in inflammation and vascular biology. Arterioscler Thromb Vasc Biol 2007;27:2514-23.

[147] Santel A, Aleku M, Keil O, Endruschat J, Esche V, Durieux B, et al. RNA interference in the mouse vascular endothelium by systemic administration of siRNA-lipoplexes for cancer therapy. Gene Ther 2006;13:1360-70.

[148] Lu C, Bonome T, Li Y, Kamat AA, Han LY, Schmandt R, et al. Gene alterations identified by expression profiling in tumor-associated endothelial cells from invasive ovarian carcinoma. Cancer Res 2007;67:1757-68.

[149] Fuchs B, Mahlum E, Halder C, Maran A, Yaszemski M, Bode B, et al. High expression of tumor endothelial marker 7 is associated with metastasis and poor survival of patients with osteogenic sarcoma. Gene 2007;399: 137-43.

[150] Dong JT, Chen C. Essential role of KLF5 transcription factor in cell proliferation and differentiation and its implications for human diseases. Cell Mol Life Sci 2009;66:2691-706.

[151] Rensen WM, Mangiacasale R, Ciciarello M, Lavia P. The GTPase Ran: regulation of cell life and potential roles in cell transformation. Front Biosci 2008;13:4097-121.

[152] Saad AF, Meacham WD, Bai A, Anelli V, Elojeimy S, Mahdy AE, et al The functional effects of acid ceramidase overexpression in prostate cancer progression and resistance to chemotherapy. Cancer Biol Ther 2007;6:1455-60.

[153] Furuichi Y. Premature aging and predisposition to cancers caused by mutations in RecQ family helicases. Ann N Y Acad Sci 2001;928:121-31.

[154] Futami K, Kumagai E, Makino H, Sato A, Takagi M, Shimamoto A, et al. Anticancer activity of RecQL1 helicase siRNA in mouse xenograft models. Cancer Sci 2008:99:1227-36.

[155] Bradley G, Ling V. P-glycoprotein, multidrug resistance and tumor progression. Cancer Metastasis Rev 1994;13:223-33.

[156] Nikiforov YE. RET/PTC rearrangement in thyroid tumors. Endocr Pathol 2002;13:3-16.

[157] de Martimprey H, Bertrand JR, Fusco A, Santoro M, Couvreur P, Vauthier C, et al. siRNA nanoformulation against the ret/PTC1 junction oncogene is efficient in an in vivo model of papillary thyroid carcinoma. Nucleic Acids Res 2008;36(1):e2.

[158] Erkizan HV, Uversky VN, Toretsky JA. Oncogenic partnerships: EWS-FLI1 protein interactions initiate key pathways of Ewing's sarcoma. Clin Cancer Res 2010;16:4077-83.

[159] Toub N, Bertrand JR, Tamaddon A, Elhamess H, Hillaireau H, Maksimenko A, et al. Efficacy of siRNA nanocapsules targeted against the EWS-Fli1 oncogene in Ewing sarcoma. Pharm Res 2006;23:892-900.

[160] Smith S, Reeves BR, Wong L, Fisher C. A consistent chromosome translocation in synovial sarcoma. Cancer Genet Cytogenet 1987;26:179-80.

[161] O’Brien S, Moore JO, Boyd TE, Larratt LM, Skotnicki AB, Koziner B, et al. 5 -Year survival in patients with relapsed or refractory chronic lymphocytic leukemia in a randomized, phase III trial of fludarabine plus cyclophosphamide with or without oblimersen. J Clin Oncol 2009;27:5208-12. 
[162] Heidel JD, Liu JY, Yen Y, Zhou B, Heale BS, Rossi JJ, et al. Potent siRNA inhibitors of ribonucleotide reductase subunit RRM2 reduce cell proliferation in vitro and in vivo. Clin Cancer Res 2007;13:2207-15.

[163] Heidel JD. Linear cyclodextrin-containing polymers and their use as delivery agents. Expert Opin Drug Deliv 2006;3:641-6.

[164] Davis ME, Zuckerman JE, Choi CH, Seligson D, Tolcher A, Alabi CA, et al. Evidence of RNAi in humans from systemically administered siRNA via targeted nanoparticles. Nature 2010;464:1067-70.
[165] Strumberg D, Schultheis B, Traugott U, Vank C, Santel A, Keil O, et al. Phase I clinical development of Atu027, a siRNA formulation targeting PKN3 in patients with advanced solid tumors. Int J Clin Pharmacol Ther 2012;50:76-8.

[166] Folkman J, Kalluri R. Cancer without disease. Nature 2004;427:787.

[167] Kudo Y, Siriwardena BS, Hatano H, Ogawa I, Takata T. Periostin: novel diagnostic and therapeutic target for cancer. Histol Histopathol 2007:22:1167-74.

[168] Villares GJ, Zigler M, Blehm K, Bogdan C, McConkey D, Colin D, et al. Targeting EGFR in bladder cancer. World J Urol 2007;25:573-9. 